\title{
THE SAVANNAH RIVER TECHNOLOGY CENTER RESEARCH AND DEVELOPMENT CLIMATOLOGY CENTER
}

R.J. Kurzeja

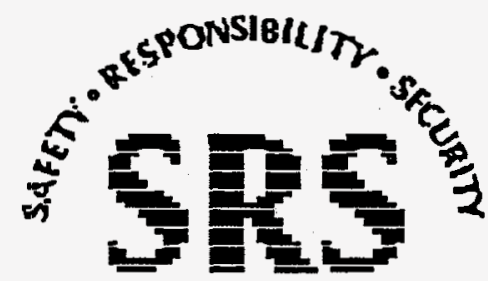

SAYANNAH RIVER SITE

Westinghouse Savannah River Company

Savannah River Technology Center

Aiken, SC 29808

Prepared for the U.S. Department of Energy under Contract No. DE-AC09-89SR18035 
This report was prepared by the Westinghouse Savannah River Company (WSRC) for the United States Department of Energy under Contract No. DE-AC09-89SR18035 and is an account of work performed under that contract. Neither the United States Department of Energy, nor WSRC, nor any of their employees make any warranty, expressed or implied, nor assume any legal liability or responsibility for the accuracy, completeness, or usefulness, of any information, apparatus, or product or process disclosed herein or represents that its use will not infringe privately owned rights. Reference herein to any specific commercial product, process, or service by trademark, name, manufacturer, or otherwise does not necessarily constitute or imply endorsement, recommendation, or favoring of the same by WSRC or by the United States Government or any agency thereof. The views and opinions of the authors expressed herein do not necessarily state or reflect those of the U.S. Government or any agency thereof.

This report has been reproduced directly from the best available copy

Available to DOE and DOE Contractors from the Office of Scientific and Technical Information, P..O. Box 62,

Oak Ridge TN 37831;

Prices available from

(615) 576-8401

FTS 626-8401

Available to the public from the National Technical Information Service, U.S. Department of Commerce

5285 Port Royal Road

Springfield VA 22161

Published in cooperation with the Management Information Services

Publications Group.

Editor: Henry A. Hancock, Jr. 


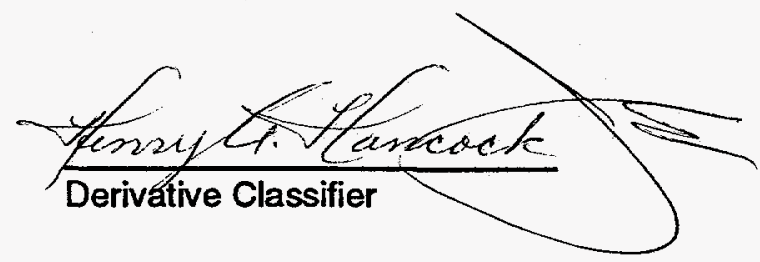

\section{THE SAVANNAH RIVER TECHNOLOGY CENTER RESEARCH AND DEVELOPMENT CLIMATOLOGY CENTER (U)}

\section{R.J. Kurzeja}

Approved by

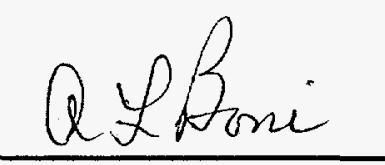

A. L. Boni

Research Manager

Environmental Technology Section

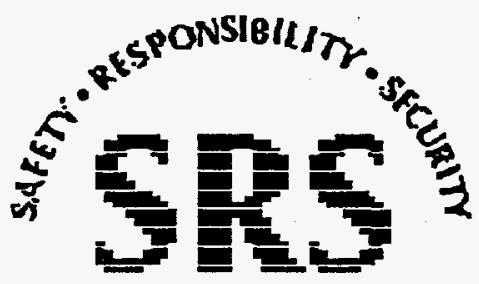

SAVANNAH RIVER SITE

Westinghouse Savannah River Company

Savannah River Technology Center

Aiken, SC 29808

Prepared for the U.S. Department of Energy under Contract No. DE-AC09-89SR18035 


\title{
The Savannah River Technology Center Research and Development Climatology Site
}

\author{
Introduction
}

The Environmental Technology Section (ETS) of the Savannah River Technology Center (SRTC) built and has operated the Climatology Site (CS) for almost 10 years. The Climatology Site provides a wide variety of meteorological support functions for Savannah River Site (SRS) operations and research.

This document describes the Climatology Site facility to familiarize present and potential users with its capabilities.

\section{History}

J.F. Schubert and D.G. Coats first proposed the construction of a climatology site in a memorandum to M.R. Buckner dated 24 July 1981. This memorandum discussed improvements to the Savannah River Site's capability to predict the transport of chemicals in the atmosphere. It noted that the accurate prediction of plume movement required measurements of the turbulence and wind profiles throughout the boundary layer, i.e., both below and above the $60-\mathrm{m}$ level of the area towers. In addition, the memorandum pointed out that the boundary layer depth, which determines the long range chemical dilution, should be measured directly and also predicted from the observed fluxes of heat, momentum, and water vapor near the surface. The installation of a SODAR (SOund Detection And Ranging) instrument at the proposed Climatology Site was suggested to measure the boundary layer depth to altitudes of 900 meters.

This memorandum also discussed the benefits from vertical profiles of turbulence and wind data would in developing climatological statistics. It proposed that models of the three-dimensional wind field be developed with data from the Climatology Site and other towers to better represent local meteorology at the Savannah River Site.

The memorandum mentioned frequent requests for meteorological information not available from the existing $60-\mathrm{m}$ tower network, e.g., solar radiation and particulate deposition: The climatology site was proposed to locate special sensors to satisfy these requests.

Significant events in the history of the climatology site are presented in Table 1. Of special note is the month of October 1984 when the tower and buildings were completed. The inspection and approval date for the facility was in December 1985, although at that time some of the instruments had not as yet been installed. 
Table 1. Significant Milestones for the Climatology Site

\begin{tabular}{|c|c|}
\hline 24 July 1981 & Climatology Site proposed by J.F. Schubert and D.G. Coats. \\
\hline 3 August 1981 & Project authorization request. \\
\hline 23 September 1981 & $\begin{array}{l}\text { Department of Energy (DOE) approval of Central Climatology Station Project SR-1498 } \\
\text { by } \$ 200,000 \text { for buildings, tower, and instruments. }\end{array}$ \\
\hline October 1984 & Construction of tower and buildings complete. \\
\hline June 1985 & Instruments received. \\
\hline September 1985 & $\begin{array}{l}\text { Tower instruments installed, data processing hardware complete, remote data } \\
\text { acquisition by SUM-X data loggers. }\end{array}$ \\
\hline 16 December 1985 & Climatology construction project closed and approved for acceptance. \\
\hline May 1986 & R.J. Kurzeja placed in charge of the climatology site. \\
\hline April 1987 & Abbreviated calibration of tower instruments. \\
\hline March 1987 & N. Odum was assigned as climatology technician. \\
\hline September 1987 & $\begin{array}{l}\text { Wind tunnel calibration of the tower instruments, SUM-X sent for repair, processing } \\
\text { cards sent for repair. }\end{array}$ \\
\hline January 1988 & Climatology tower data available on VAX 8550 , but not archived. \\
\hline May 1988 & $\begin{array}{l}\text { STABLE field experiment, SUM-X repaired, Bistatic SODAR used in STABLE } \\
\text { experiment. }\end{array}$ \\
\hline January 1989 & Begin archiving of the tower data on the VAX data base. \\
\hline April 1989 & $\begin{array}{l}\text { Modified data acquisition software to store first and last values for pressure, rainfall, } \\
\text { and evaporation. }\end{array}$ \\
\hline May 1989 & R. Holland and J. Hamilton were designated as climatology technicians. \\
\hline October 1989 & Completed Climatology Display Program. \\
\hline January 1991 & $\begin{array}{l}\text { Semi-annual calibration of tower instrument began with procedure ETSP T101, ETSP } \\
\text { T102, ETSP T103, ETSP T-100A, ETSP T-100B, ETSP T107. }\end{array}$ \\
\hline July 1991 & Strip chart plots of 15-minute climatology data generated for 1990 to the present. \\
\hline May 1993 & Height of the ground-level bivane and anemometer raised from 2 to 4.5 meters. \\
\hline
\end{tabular}

An important milestone occurred in January of 1989 when the climatology data was added to the Environmental Technology Section's permanent archive on the VAX 8550. Prior to this time the tower instruments could only be accessed with the SUM-X data loggers. 
The Climatology Display program was completed in October of 1989. This Weather INformation and Display Systems (WINDS) menu program permitted easy access and display of the present and past climatology data.

A number of significant milestones occurred in 1991. In January the instruments were added to the semi-annual calibration program followed for SRS area towers. This program resulted in improved and defensible data quality. The field instruments also became subject to a rigorous semi-annual calibration program in July of 1991. A new grounding system was installed for the tower and data building in September, which reduced the incidence of lightning damage to the instruments and related electronics.

In January 1993 strip chart plots were completed for climatology data beginning in January of 1990. These plots now provide a quick inspection of all climatology data. They enable easy comparisons of the sensor data with other similar sensors or with theoretical predictions. The capability to write files of archived data. was also added.

\section{Facility Description}

The climatology site is situated in a grass fenced area approximately 120 meters by 120 meters in the Central Shops (N) area. The site consists of a 61-m tower, instrumented at 4 levels, a concrete pad near the tower, and 2 buildings which house data acquisition equipment. The basic description of the site is presented in Table 2.

Table 2 Basic Description of the Climatology Site

\begin{tabular}{|ll}
\hline Site elevation & $90.2-\mathrm{m}$ above Mean Sea Level (MSL) \\
Location of 61-m tower & $\begin{array}{l}33^{\circ} 14^{\prime} 42^{\prime \prime}\left(33.245^{\circ}\right) \text { North } \\
81^{\circ} 39^{\prime} 2^{\prime \prime}\left(81.651^{\circ}\right) \text { West }\end{array}$ \\
Building Dimensions & $\begin{array}{l}\text { Storage Building 623-28G }-3.0 \times 6.0 \text { meters } \\
\text { Data Acquisition Building 623-27G }-3.0 \times 6.0 \text { meters } \\
\text { Tower 623-266 } \\
\text { Fenced enclosure }\end{array}$ \\
\hline
\end{tabular}

The Climatology Site is situated near the geographical center of the Savannah River Site (see Figure 1). This location was chosen as representative of the site and because of ready access to electrical power and phone communications. 
The environment immediately surrounding the climatology site is shown in Figure 2. Permanent structures in the vicinity include one-story storage buildings 714-5N, $-6 \mathrm{~N}$, and $-7 \mathrm{~N}$ northwest of the site and the Ford building (690-N) east of the site. Railroad tracks run south of the site. The 100-200 meters surrounding the site includes parking lots, grassy areas, and a few trees. Figure 3 shows the climatology site as viewed from the southeast corner of the fenced area, looking toward the west. In 1990 the area immediately around the site fence to the north, east, and south came into use as a laydown yard.

Figure 4 shows the climatology site in more detail, illustrating the parking lot, buildings, sidewalk, tower, and pad areas. The buildings nearest to the tower are the storage building, $623-28 \mathrm{G}$, and the data acquisition building, $623-27 \mathrm{G}$.

Table 3 Climatology Site Instruments

Tower Instruments

\begin{tabular}{|c|c|c|}
\hline Description & & Tower elevation (meters) \\
\hline Wind direction & $\begin{array}{l}\text { Teledyne Geotech Bivane } \\
\text { Model } 1585\end{array}$ & $2^{*}, 18,36,61$ \\
\hline Wind speed & $\begin{array}{l}\text { Teledyne Geotech } \\
\text { Anemometer, Model } 1564 \mathrm{~B}\end{array}$ & $2^{*}, 18,36,61$ \\
\hline Temperature & $\begin{array}{l}\text { Teledyne Geotech Platinum } \\
\text { Resistance, Model T-210 }\end{array}$ & $2,18,36,61$ \\
\hline Dew Point & $\begin{array}{l}\text { Teledyne Geotech } \\
\text { Model DP 200-B } \\
\text { Teledyne Geotech 327-C }\end{array}$ & $2,18,36,61$ \\
\hline
\end{tabular}

* Raised to 4.5 -m in May 1993

Field Instruments

\begin{tabular}{|c|c|c|}
\hline Description & & Elevation (meters) \\
\hline Solar radiation & $\begin{array}{l}\text { Eppley Black and White } \\
\text { Pyranometer, 8-48 }\end{array}$ & 2 \\
\hline Direct solar radiation & Eppley Pyrheliometer, 3060 & 2 \\
\hline Net radiometer & Qualimetrics, 3040-A & 2 \\
\hline Rainfall & $\begin{array}{l}\text { Belford Tipping Bucket } \\
\text { 5-405HA }\end{array}$ & 1 \\
\hline Evaporation Pan & Qualimetrics, 6488-A & 0.2 \\
\hline Wet and dry precipitation & Aerochemn Metrics 301 & 1 \\
\hline
\end{tabular}

Soil Temperature $2.5,15.2$, and $30.5 \mathrm{~cm}$ from base of tower

Instruments in 623-27G

\begin{tabular}{|lll|}
\hline Description & & Elevation (meters) \\
\hline Atmospheric Pressure & Rosemont 1332A10 & 2 \\
Atmospheric Pressure & Princo Mercury Barometer & 1 \\
\hline
\end{tabular}

Remote Sensing Instruments

\begin{tabular}{|lll|}
\hline Description & Range of measurement \\
\hline Boundary Layer measurements & SODAR - XonTech Bistatic & 60 to 800 meters \\
\hline
\end{tabular}


The instruments currently located at the climatology site are listed in Table 3. They are divided into four categories; Tower Instruments, Field Instruments, Instruments in Building 623-27G, and Remote Sensing Instruments.

The Tower instruments measure temperature, dew point, wind speed, and wind direction. Identical instruments are installed at each of the 4 tower levels to ensure comparability between levels.

The Teledyne Geotech bivane and cup anemometers installed on the tower are shown in Figure 5. More detailed information on these instruments can be found in Reference 1. These instruments provide data every 1.5 seconds averaged over 15 -minute periods and then archived in the VAX 8550 database. An example of the archived bivane data (azimuth and elevation) is presented in Figure 6.

Each 1.5 -second data point is averaged over 15-minute period and archived by the VAX 8550 as the mean air speed. In addition, each data point is compared to the mean and the deviation is then squared and divided by the sum of the squares of the fluctuation and archived as the standard deviation of the air speed. This standard deviation is considered the wind turbulence. Turbulence is best measured with fast response sensors, i.e., sensors with time constants of 1 second or less. Of the tower instruments, the most suitable for this purpose are the anemometer and bivanes (time constants $\sim 1 \mathrm{sec}$ ). Typical measured wind speeds and standard deviations for the anemometer are shown in Figure 7.

Temperature and dew points are also measured at four levels on the tower in continuously aspirated radiation shields. These sensors are calibrated with a common standard so that slight differences can be detected (Figure 8).

Field instruments are located on or near the concrete pad south of the tower (see Figure 9). They include soil temperature probes, the short wave pyranometer, pyrheliometer, long wave radiometer and rain gage, deposition pans, and evaporation pan. These instruments are used for both routine and special functions. For example, the pyrheliometer and deposition gages are used on an as-needed basis.

Soil temperatures are measured at depths of $2.5 \mathrm{~cm}, 15.2 \mathrm{~cm}$, and $30.5 \mathrm{~cm}$ approximately 5 meters from the base of the tower. The soil and air temperatures can be used to determine the thermal budget near the ground, i.e., the heat transfer to and from the soil surface layer from the atmosphere above and the deeper soil layers below. Because of the relationship between soil temperatures and the temperatures of the air above, they are plotted together (Figure 8).

The black and white pyranometer and pyrheliometer are shown in Figures 10 and 11. The black and white pyranometer measures solar radiation from the whole sky (both direct sun and scattered radiation) for the wavelengths from $0.28 \mu \mathrm{m}$ to $2.8 \mu \mathrm{m}$. The pyrheliometer measures radiation from the direct sun the range $0.5 \mu \mathrm{m}$ to $2.8 \mu \mathrm{m}$. The pyranometer operates 24 hours each day whereas the pyrheliometer is only operated on an as needed basis. 
The rain gage and evaporation pan are shown in Figures 12 and 13. The rain gage is the tipping bucket variety which sends and electrical signal for each bucket tip $(0.01$ inches of rain). The evaporation pan is a device which monitors the water level in a pan approximately $1.3-\mathrm{m}$ across and $15-\mathrm{cm}$ deep. The evaporation pan measures both evaporation and rainfall. These instruments are operated 24 hours a day.

The deposition instrument is shown in Figure 14. It consists of two containers which are alternately covered or uncovered depending on whether it is raining or not. The contents of the containers are later analyzed for specific chemicals. This instrument is seldom used since it requires additional chemical analysis.

There are two instruments are located in the data acquisition building, 623-27G: the Rosemont barometric pressure sensor and the Princo mercury barometer. The Rosemont pressure sensor is sampled every 1.5 seconds and is calibrated with the Princo barometer.

Weekly strip chart plots of data are generated to monitor the performance of the instruments. The plots were designed for meaningful analysis as can be seen from Figure 15, which shows a weekly plot of solar radiation, barometric pressure, rainfall, and evaporation water depth. Also shown are the theoretical clear-sky solar radiation, and Augusta's Bush Field barometric pressure readings (corrected for elevation difference). The rain gage data and evaporation pan are shown with the same scale.

Remote sensing instruments obtain data through analysis of electronic, acoustic, or optical energy emitted by or scattered from the sampling volume in question. The climatology site SODAR measures atmospheric turbulence, wind direction, and speed through analysis of an audible sound pulse reflected back from the air above the instrument. The strength of that returned echo is proportional to the turbulent energy while the Doppler shift of the emitted pulse's frequency is a measure of the wind speed.

A bistatic SODAR is defined by separated transmitting and receiving antennae (Figure 16). This geometry is sensitive to both atmospheric temperature and speed fluctuations since all scattering volumes are located in a single vertical column. The SODAR transmits a sound pulse every few seconds and produces an analyzed output signal every 15 minutes. a photograph of the transmitting/receiving antennae in the climatology bistatic system is shown in Figure 17. The location of the two receiving antennae in this system is shown in Figure 18. The receiving antennae are used to measure the east-west and north-south wind components.

Figures 19 and 20 illustrate another kind of SODAR output - the wind table. The wind table shows the wind speed and direction at 20 levels from 60 to 630 meters in 30 meter increments. Also shown are the wind components, standard deviation of the wind and returned echo power (echo strength).

\section{Data Flow and Archiving}

The data processing design at the climatology site was based on the existing designs at the area meteorological towers and at the WJBF TV tower in Beech Island, SC (Figure 
21). The output from the sensors is sent to signal processor modules which convert the signals to DC voltages (0-5 VDC). The signal processor modules are connected to an Analog Devices MicroMac processor which samples the sensors, converts the analog signal to a digital signal, then transmits a stream of data to the SRTC over a dedicated modem/phone line. The data is received by the VAX computer in Building 773-A where a VAX 8550 processes, averages, and archives the data. A complete set of data is transmitted every 1.5 seconds.

The backup data acquisition system was a SUM-X Model 405 data logger which converted the analog signals to digital and stored up to one week of data. SUM-X data was accessed by the VAX 8550 over a separate phone line. This data logger was destroyed by lightning in July of 1993.

An alternate backup system was purchased in 1988. It consists of an HP 9000 minicomputer and an HP 3852A data acquisition system. Unlike the SUM-X, the HP system is fully programmable and permits data processing at the climatology site. It can also store several months of data. Transfer of the data to the VAX 8550 takes place via modems and phone lines by the file transfer protocol KERMIT.

Before January of 1989 data from the climatology site could be obtained only from the SUM-X data logger. Permanent data summaries from this period are available in hard copy form for a few periods of time. After 1989 climatology data was archived on the VAX 8550 computers.

Calibration of the climatology instruments prior to 1991 was carried out at irregular intervals; one or two times per year. The instrument calibration schedule was substantially improved after 1991 when procedures ETSP T-100A to ETSP T107 were implemented. An example of a typical calibration form from these procedures is illustrated in Figure 22.

Quality assurance of the data is accomplished in three steps. The semi-annual calibrations document the "as-found" and "as left" performance of the instruments. The data is inspected daily to monitor performance and carry out timely maintenance and repair. In addition, weekly strip chart plots of the data permit easy identification of "out-of-service" times and "questionable" data. Finally log books identify problems and the time periods when these problems occurred.

\section{Uses of the Climatology Site}

The climatology site fulfills several roles at the SRS. The first is general site support for daily weather-related problems. Climatology data is most often accessed via the Climatology Display Program, which is part of the VAX WINDS system menu. VAX users can access the most recent data as well as past data from one of the many VAX terminals on site. A sample display is shown in Figure 23.

This display shows all of the information available at the climatology site except for the SODAR data. The tower data is shown for all levels. Besides measured data, certain derived values are also shown. For example, the relative humidity and water vapor mixing ratio are not measured directly but rather calculated from the 
temperature and dew point. The measured solar radiation is compared to an expected clear-sky value by computing the ratio of measured to clear-sky radiation.

The program also computes the changes in pressure, rainfall, and evaporation over 15 minutes, 1 hour, 3 hours, and 24 hours. Other useful information is displayed. For example, Bush Field pressure, temperature, dew point, and relative humidity are shown. Selected data from the WJBF TV tower and area towers is also displayed.

Since the climatology site is the only SRS tower which measures near surface finds, it is frequently accessed for operational problems when surface winds must remain below some predetermined limit. For example, some waste tanks can only be opened when the wind is not strong enough to disturb chemicals in open containers.

Climatology data can be quite useful for assessing the effects of severe weather. For example, snowfall is rare at the SRS but can be very disruptive to normal operations. An important variable in determining whether snow will accumulate is the soil temperature, which is only available at the climatology site.

The climatology site is also used to provide advisory information for Emergency Response activities. An important parameter for emergency response is the mixing depth of the boundary layer, which governs the thickness and hence dilution of chemicals released into the atmosphere. An excellent instrument for measuring this quantity is the SODAR since it measures the turbulence directly (see Figure 19). Direct measurements of the mixing depth can be obtained up to approximately 800 meters. Mixing depths for elevations greater than 800 meters must be obtained indirectly by supplementary calculations.

The assessment of accidental releases at night can be particularly difficult since the wind and turbulence can vary rapidly with height. An example of this phenomena is shown in Figures 24 and 25. Figure 24 shows the speed and direction for four successive 15-minute periods between 3:00 am and 4:00 am EST on 8 April 1993. During this period the wind direction varied by 70 to 80 degrees between the surface and 61 meters. The wind speed behavior was also quite variable and even included the formation of a low-level jet near 36 meters after 3:30 am.

The variation of wind speed and direction with height results in different cloud trajectories, depending on the release height. Figure 25 shows the trajectory of three air parcels released simultaneously at 3:00 am on 8 April from levels 18, 36, and 61 meters. This behavior is remarkable and could only be identified with multiple levels of wind data.

The climatology site has also been used for engineering applications. In 1987 an important issue at the SRS was the cooling efficiency of $L$ Lake. The state of South Carolina established a maximum permissible temperature for $L$ Lake which required operation of the $\mathrm{L}$ reactor at less than full power during peak summer heating. A model for $L$ lake heating was developed which required input of temperature, wind speed, humidity, and solar radiation. The model predicted the $L$ lake temperatures so that operating power could be adjusted to avoid exceeding the mandatory temperature. The operational aspects of the program were to involve the climatology site which 
would supply the necessary data in real time. Although the model was used only for test calculations, the benefit of the wide variety of information available at the climatology site was obvious.

A similar problem occurred in 1993 with the In-Tank Precipitation project. In this case it was necessary to calculate the maximum heating of waste tanks during summer months, when the temperature was a maximum, wind speeds low, and solar heating a maximum. For this problem climatology data was supplied to the Nuclear Engineering Section of the SRTC.

Another waste tank problem was solved in 1993 with the aid of climatology data. This problem was concerned with oxygen enrichment in waste tanks forced by natural atmospheric pressure fluctuations. Climatology pressure data was analyzed to determine the maximum pressure fluctuations over 8 and 24-hour period. 4

Climatology data is also used in support of studies by other institutions. In December of 1992 the University of Georgia began a study of pesticide flow in surface water. The Savannah River Site will provide measurements of winds, temperature, humidity, evaporation, solar radiation, and rainfall for this study over the next year.

The climatology site has also been used to monitor unusual weather at the SRS. One such period was in the second half of 1990 when heavy rains were observed at the SRS in three months. Figure 26 shows one period of heavy rain on 22 August 1990 when 5.8 inches of rain fell between midnight and 5:00 am. The 15-minute resolution of this rainfall by the climatology rain gage is necessary to relate rainfall to observed flooding and to historical extreme rainfalls. 5

Another unusual weather event monitored by the climatology instruments was the socalled "Storm-of-the-Century" on 12-13 March 1993. This winter storm was accompanied by the lowest pressure ever measured at Bush Field. The lowest pressure recorded at the climatology site from this storm was $957.6 \mathrm{mb}$. A trace of the pressure change at the climatology site is shown in Figure 27.

The climatology site has also provided information for special field projects. The most important of these was the STABLE project. This project was planned and operated by the Department of Energy by the SRS and focused on chemical dispersion in the nocturnal boundary layer. A field observation program was carried out in April of 1988 which made use of the SRS tower network supplemented by additional intensive measurements. North Carolina State University participated in this program by installing special turbulence instrumentation at the climatology site. These instruments included a sonic anemometer and temperature probe at $\mathbf{3 6}$ meters. A bistatic SODAR was also in operation at the climatology site at this time. Research from this project is reported in papers by Weber and Kurzeja (1992) and Parker and Raman (1993).

In 1986 the SRS participated in a joint study with Penn State University on atmospheric dispersion. A SODAR was operated at the climatology site during releases of sulfur hexafloride from the $\mathrm{H}$ Area. Downwind concentrations were measured from the Environmental Technology's TRAC vehicle. These measurements were used to investigate the value of SODARs in operational dispersion forecasting. 
Future Developments

Changes to the climatology site since it first became operational in $\mathbf{1 9 8 5}$ have focused mainly on improving its basic mission to provide special meteorological data for the SRS. In the next few years this course of action will continue by with a focus on local data acquisition and processing.

The remaining uncompleted components of the original site design are the net radiometer and a continuously operating SODAR. Net radiometers measure short and long-wave radiation and the difference (net) between total upward and total downward radiation. They are used to determine the thermal budget near the ground. The thermal budget in turn affects the turbulence and depth of the boundary layer.

Although new radiometers have been used for decades, their reliability and durability have not been good. In fact, one reason why the original net radiometer has not been replaced has been the lack of reliable commercial instrumentation. Recent testing, however, has indicated that an aspirated commercial net radiometer is available which yields good data under a wide range of conditions. In addition, at least one commercial pyrameter (infrared sensing radiometer) is also available which could be used in conjunction with a pyranometer to measure net radiation. Thus, the addition of one of these instruments is a top priority for the near future.

The thermal budget can be calculated with a numerical model if instrumentation to measure long-wave radiation is available. Furthermore, this numerical model could be used to predict measured quantities to verify instrument performance and establish necessary accuracy levels. Thus, a valuable addition to the climatology site is software to determine the surface energy budget in real time using available instrumentation. This model could also be used to characterize boundary layer behavior for emergency response and engineering applications.

Another valuable addition to data collection at the climatology site would be soil moisture. This quantity is difficult to measure and highly variable from place to place. Efforts are underway to acquire a suitable recording instrument for this task. However, before this can be achieved, a regular manual sampling program is being considered. This program would consist of measuring the weight of soil samples before and after baking at $105^{\circ} \mathrm{C}$ to drive off the moisture. This measurement would be performed by a technician one per week at the climatology site and a forested location near the site. This data would be used as input to atmospheric models and for energy budget studies.

The climatology site's mission to measure a range of atmospheric variables for longterm studies and special programs require a flexible data acquisition program. As mentioned in Data Flow and Archiving, the data acquisition for the climatology site was modeled after the area towers and the WJBF TV tower. This scheme specifies a uniform sampling rate ( 1.5 seconds) for all sensors. While this course of action was convenient and efficient, it has drawbacks. First since the climatology sensor response times vary from instrument to instrument, a variable sampling rate is desirable. Second, some applications require a special sampling progression rather than sampling at random. For example, it is desirable to sample all tower variables at a given level as 
quickly as possible to create a "snapshot" of the sensors. This enables the combination of sensor information as in, for example, a heat flux calculation which involves the bivane, anemometer, and temperature readings. Finally, a programmable system is desirable for special projects, for example, project STABLE.

Scheduled for completion in the near future is data acquisition software for the climatology SODAR. As noted previously, output data from the SODAR currently goes to a floppy disk or a printer. Thus, it can only be recovered through a visit to the site, and subsequent manual transfer to another computer. Future plans call for automatic transfer of SODAR data to the HP 9000 computer and then transfer to the VAX 8550 via modem and phone line. This will permit real-time use and archiving of SODAR data along with the other climatology data.

\section{References}

1. Parker, M.J., R.P. Addis, C.H. Hunter, R.J. Kurzeja, and A.H. Weber, 1992. The 1987-1991 Savannah River Site Meteorological Data Base. WSRC-RP-92-598. Westinghouse Savannah River Company., Aiken SC.

2. Weber, A.H. and R.J. Kurzeja, 1991, Nocturnal Planetary Boundary Layer Structure and Turbulence during the Project STABLE Field Program. J. Appl. Meteor., 30,1117-1133.

3. Parker, M.J. and Sethu Raman, 1993, A Case Study of the Nocturnal Planetary Boundary Layer over Complex Terrain. Boundary Layer Meteorology, to be published.

4. Kurzeja, R.J. and A.H. Weber, 1993, Atmospheric Pressure Fluctuations and Oxygen Enrichment in Waste Tanks, WSRC-TR-93-232, Westinghouse Savannah River Company, Aiken SC.

5. Addis, R.P. and R.J. Kurzeja, 1992, Heavy Rainfall at the Savannah River Site in July, August, and October of 1990, WSRC-TR-92-136, Westinghouse Savannah River Company, Aiken SC. 


\section{List of Figures}

1. Map of the SRS showing the location of the climatology site in the Central Shops area.

2. Map of the Central Shops area showing the Climatology site.

3. Photograph of the climatology site 61-meter tower and Buildings 623-27G and 623-28G.

4. Close-up map of the climatology site.

5. Photograph of the bivane and anemometer at the 4.5-meter level.

6. Weekly plots of the bivane azimuth and elevation. The lover four traces (from the bottom up) are the 4.5, 18,36 , and 61 meter azimuth. The top four traces are the $4.5,18,36$, and 61 meter elevation from the middle to the top. Note that the azimuth scale is linear (0-400 degrees). The elevation scale is linear between 0 and 10 degrees and logarithmic for angles greater than 10 degrees, i.e., 10xlog (elevation). Elevation angles less than -10 degrees are plotted as $-10 x \log \mid$ elevation $A$ |

7. Weekly plots of the anemometer speed and standard deviation of the azimuth (sigma azimuth). The scale is logarithmic for the speed (lower four traces) and linear for the standard deviation (upper four traces).

8. Weekly temperature plots for three soil probes, and four sensors on the $61-\mathrm{m}$ tower. The 12 -in. soil temperature is plotted in actual centigrade temperature, while the other curves have $20,40,60, \ldots 120$ degrees added to them for clarity.

9. Detail of the instruments at the base of the 61-m tower at the Climatology site.

10. The Eppley Black and White Pyranometer.

11 The Eppley Pyrheliometer and Solar Tracker.

12. The Belford Tipping Bucket Rain Gauge, Model 5-405HA.

13. The Qualimetrics Model 6488-A Evaporation Pan.

14. The Wet and Dry Deposition Instruments

15. Weekly plots of the solar radiation, barometric pressure, rain gauge, and evaporation pan at the climatology site. The dashed line on the solar radiation plot shows the theoretical clear-sky expected value for each day. The dashed pressure plot is for Bush Field in Augusta GA (corrected for elevation difference). The dashed line in the top half of the figure is the depth of water in the evaporation pan. Note the manual refill of the pan on 22 July. The rain gage is indicated with a solid line. Note the reset which occurred on 20 July.

16. Geometry for the Bistatic SODAR at the Climatology site.

17. The vertical Bistatic Antenna at the Climatology site.

18. Locations of the Bistatic SODAR at the Climatology site.

19. Return echo from the Bistatic SODAR. The darkness of the shading is proportional to the magnitude of turbulence..

20. Wind table from the Bistatic SODAR. The heights are in meters. 
21. Current and proposed data flow schematic for the climatology site.

22 Pyranometer Calibration Form - FORM OP-PY (Rev 1).

23. Climatology display program on the WINDS (Weather INformation and Display System) on the VAX 8550 computer.

24. Plots of wind data for 15-minute periods between 3:00 am to 4:00 am on 8 April 1993.

25. One hour air trajectories of air parcels at 18,36, and 61-m between 3:00 am and 4:00 am on 8 April 1993 .

26. Rainfall in inches on 22 August 1990 at the climatology site between 12:00 am and 5:00 pm.

27. Pressure trace at the climatology site during the "Storm-of-the-Century", 12-14 March 1993 


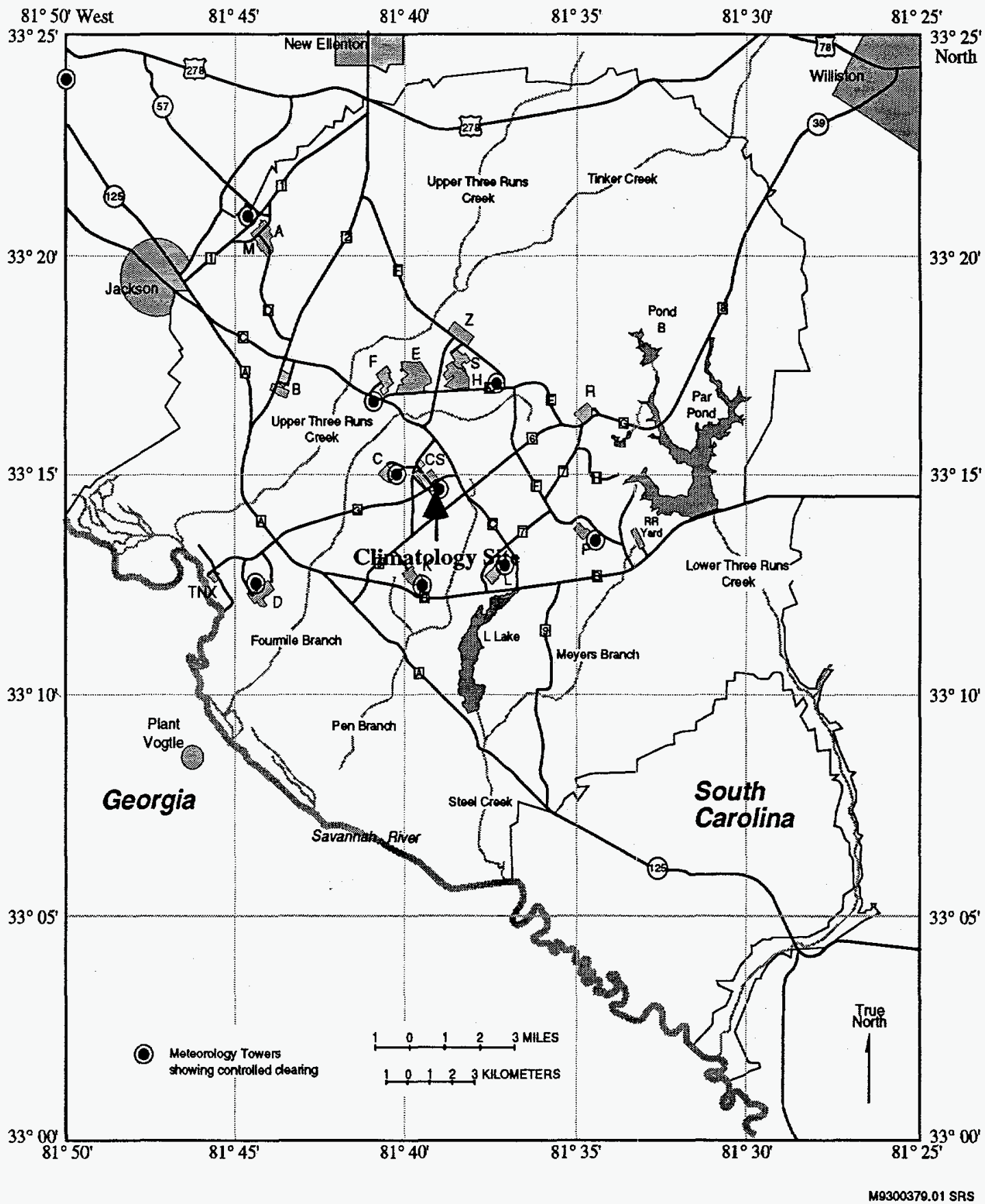

Figure 1. Map of the SRS showing the location of the Climatology Site. 


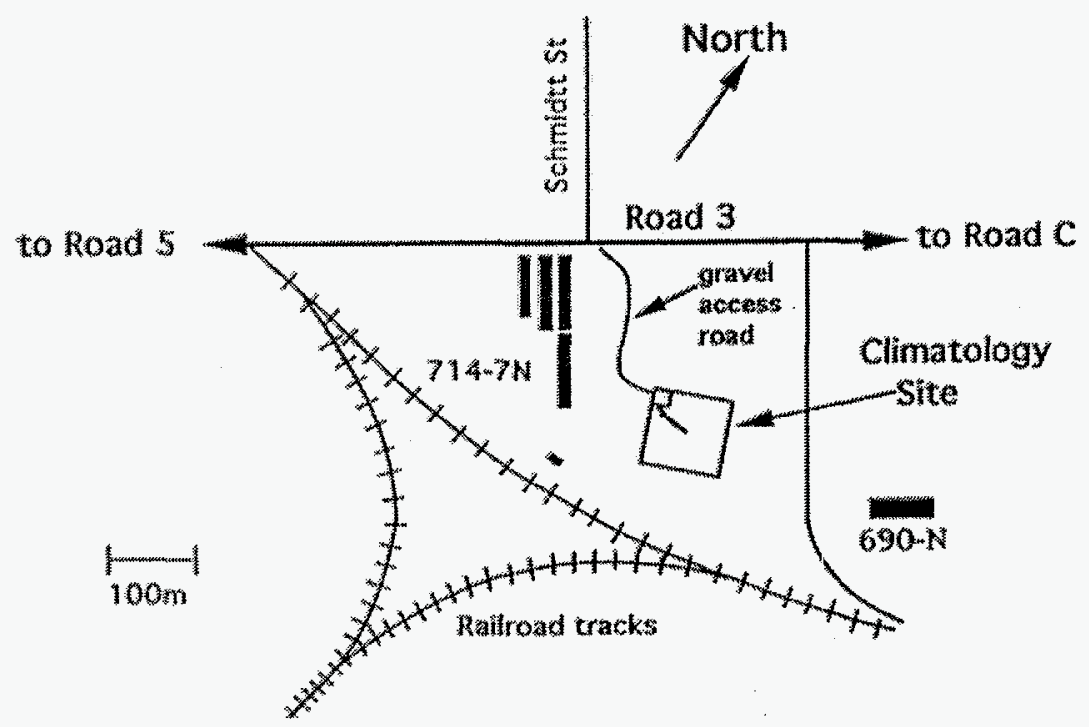

Figure 2. Map of the Central Shops area showing the Climatology Site. 


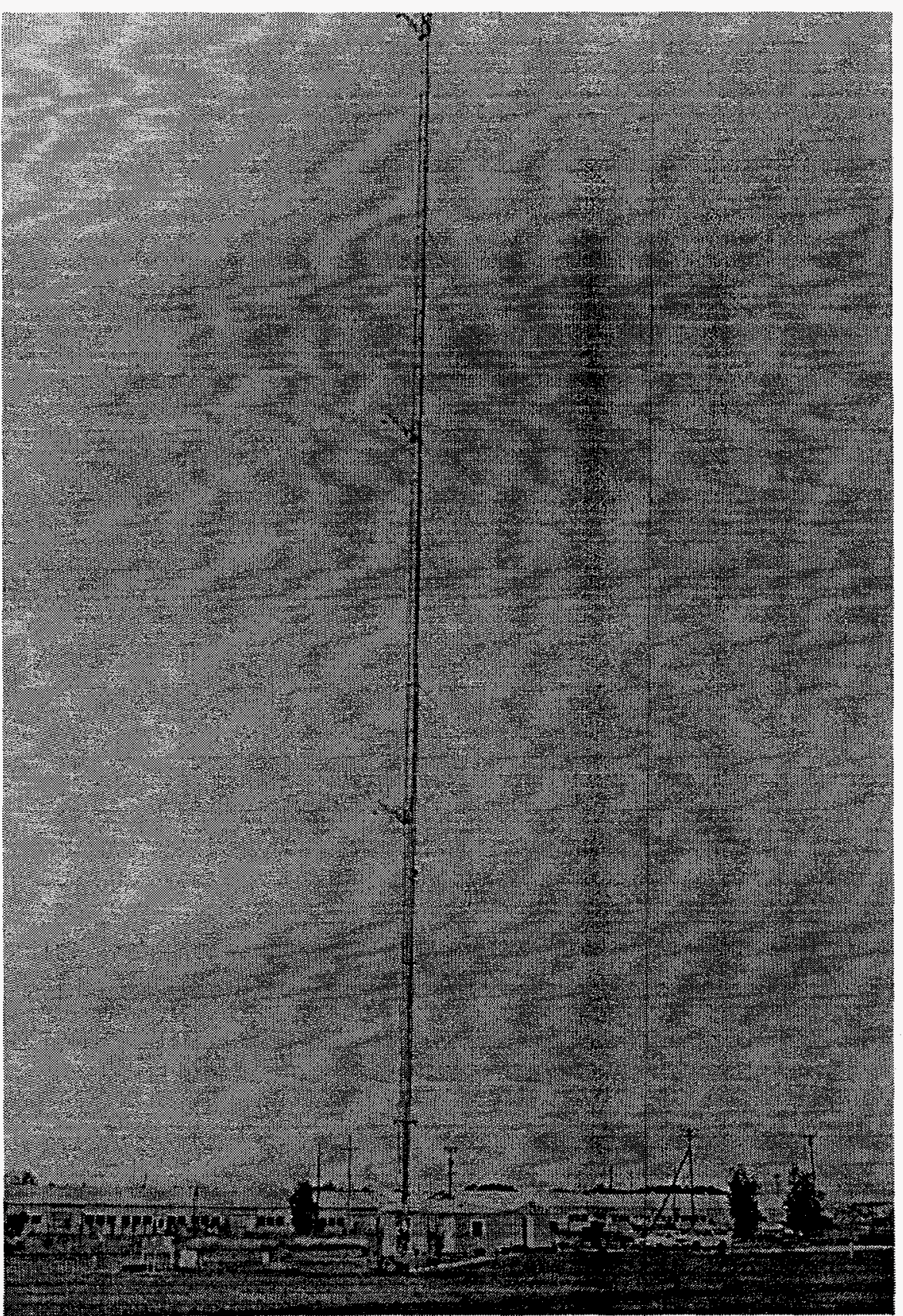

Figure 3. Photograph of the Climatology site 61-meter tower and buildings $623-27 \mathrm{G}$ and $623-28 \mathrm{G}$. 


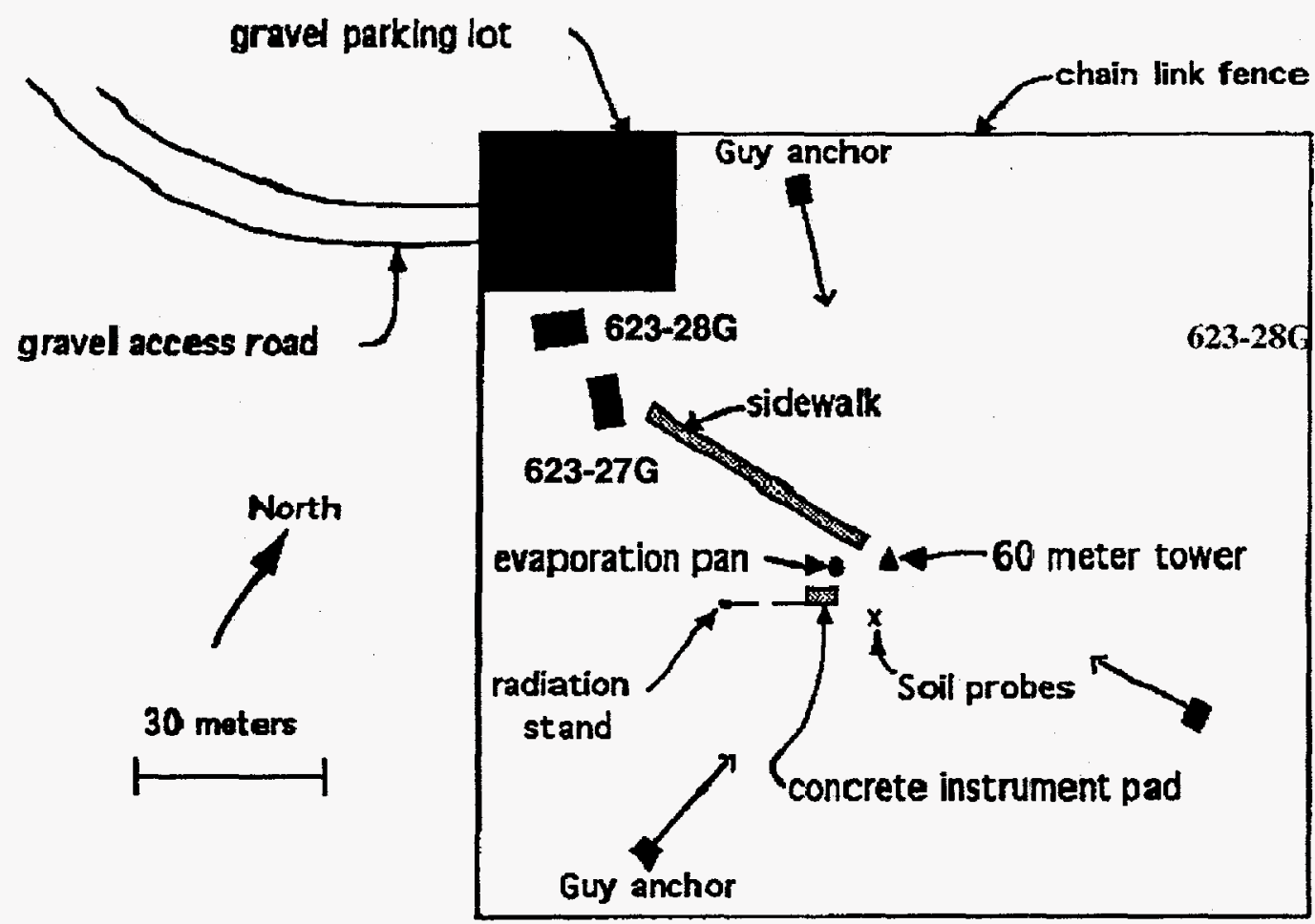

Figure 4. Close up Map of the Climatology site. 


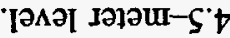

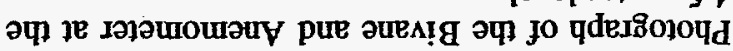

•ร ว.Inกิ!ม

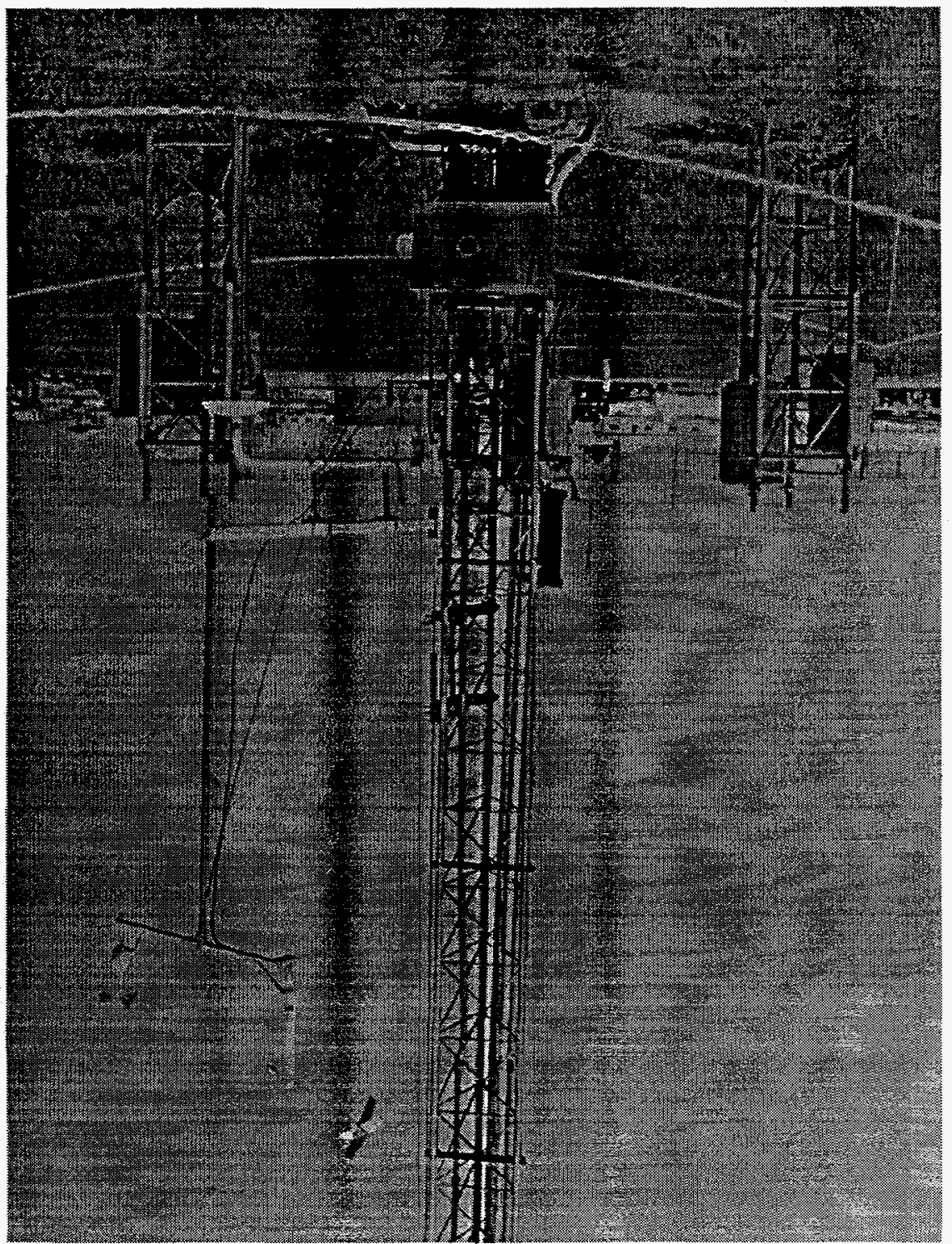




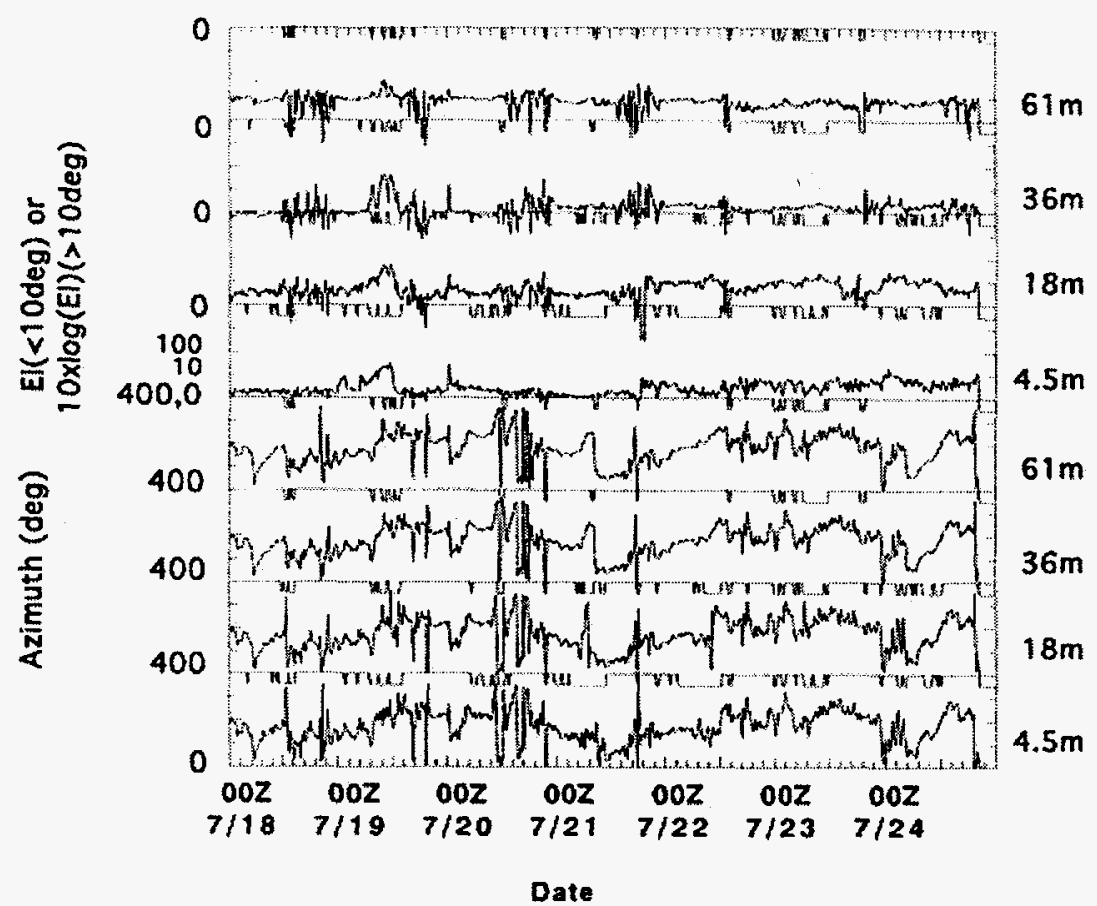

Figure 6. Weekly plots of the bivane azimuth and elevation. The lower four traces (from the bottom up) are the 4.5, 18, 36, and 61-meter azimuth. The top four traces are the 4.5, 18, 36, and 61-meter elevation (from the middle to the top). Note that the azimuth scale is linear (0-400 degrees). The elevation scale is linear between 0 and 10 degrees and logarithmic for angles greater than 10 degrees, i.e., $10 x \log$ (elevation). Elevation angles less than -10 degrees are plotted as $-10 x \log$ ( elevation $\mid$ ). 


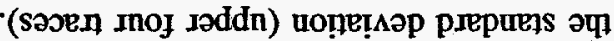

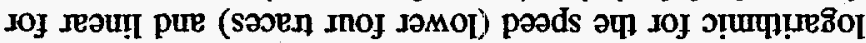

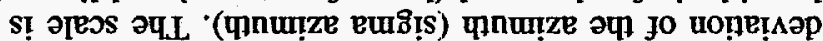

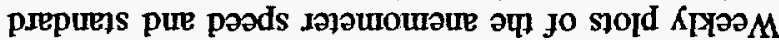

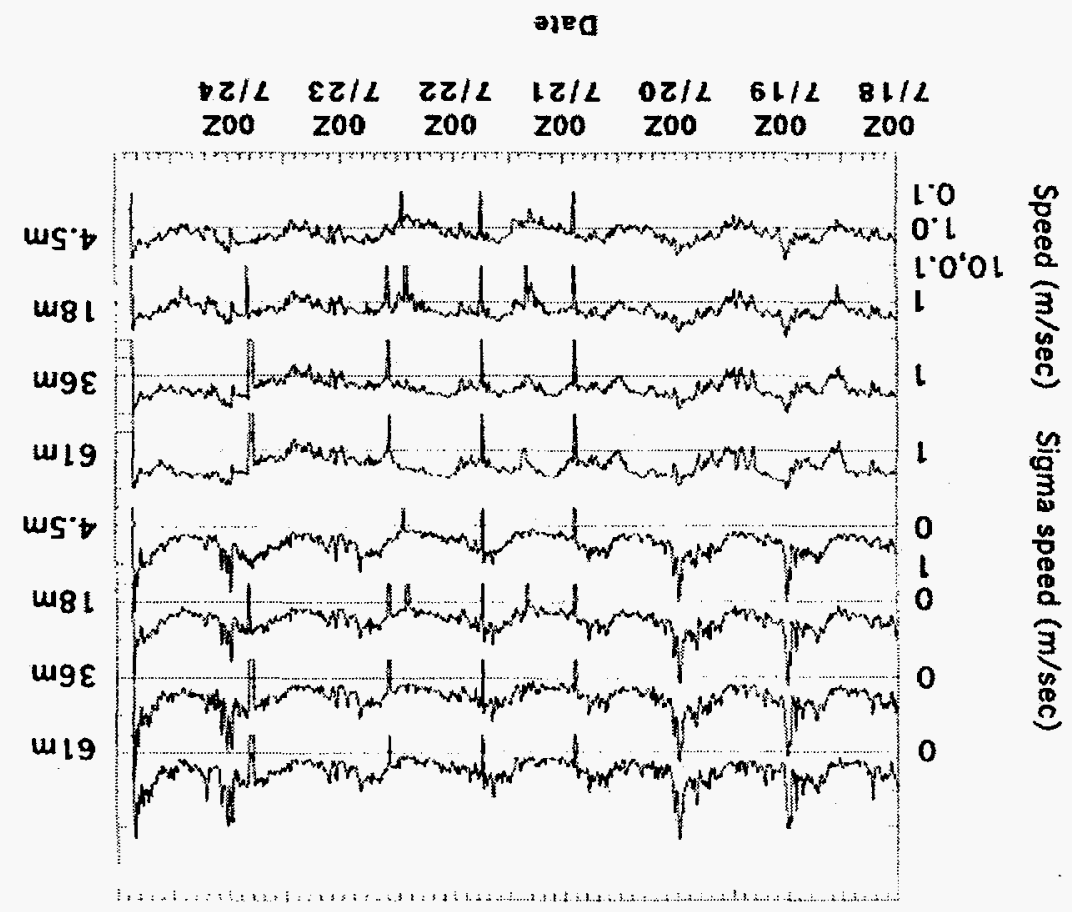




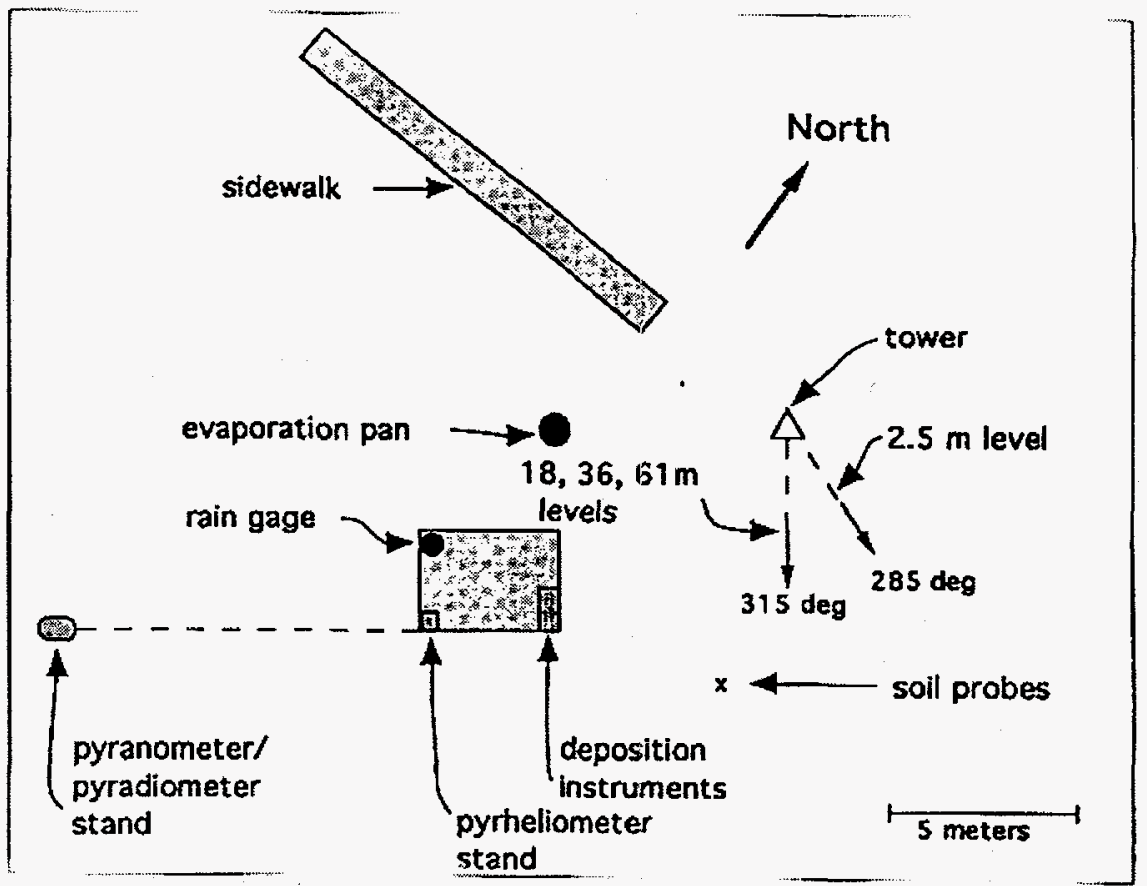

Figure 9. Detail of the instruments at the base of the 61-meter tower at the Climatology site. 


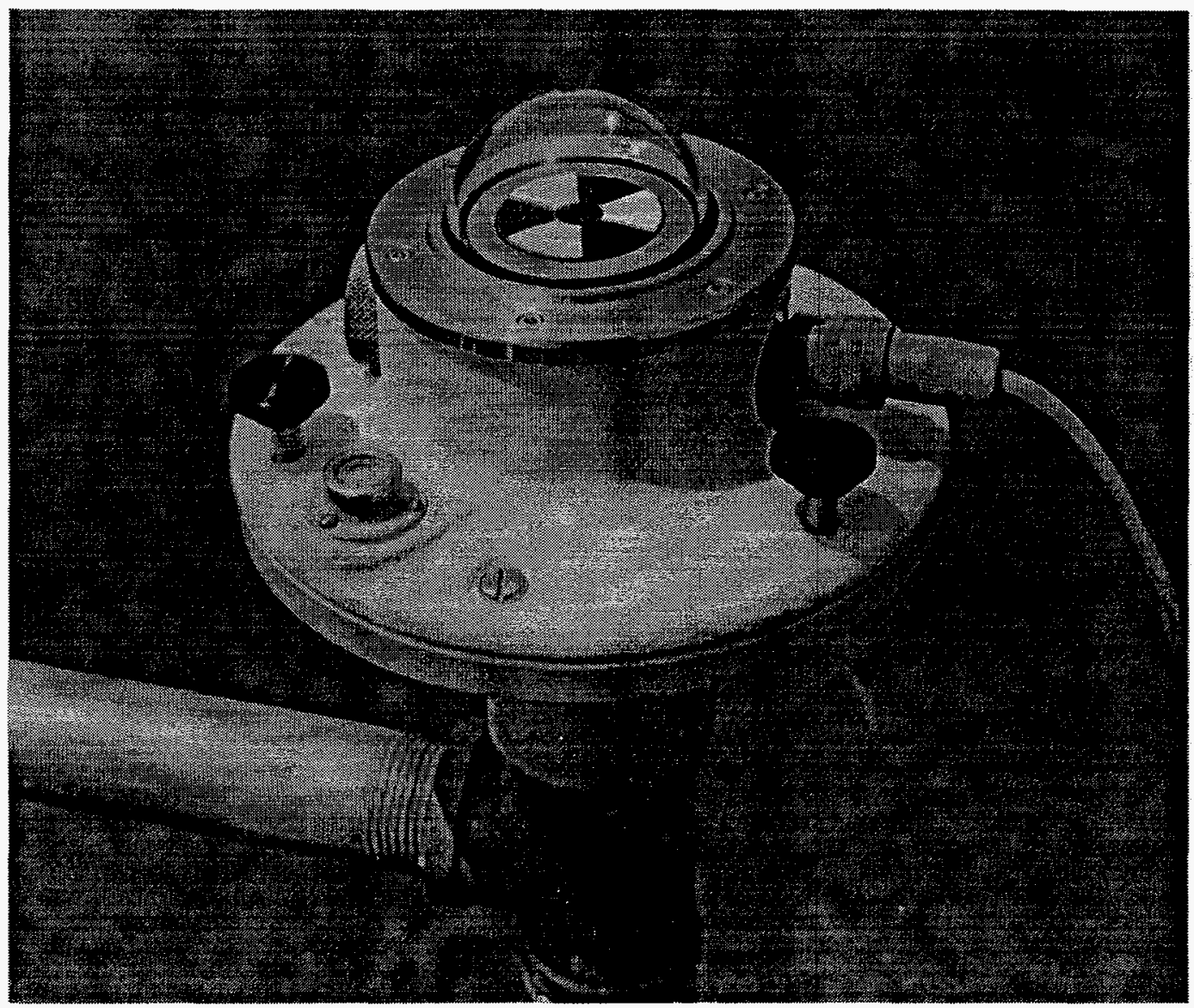

Figure 10. The Eppley Black and White Pyranometer. 


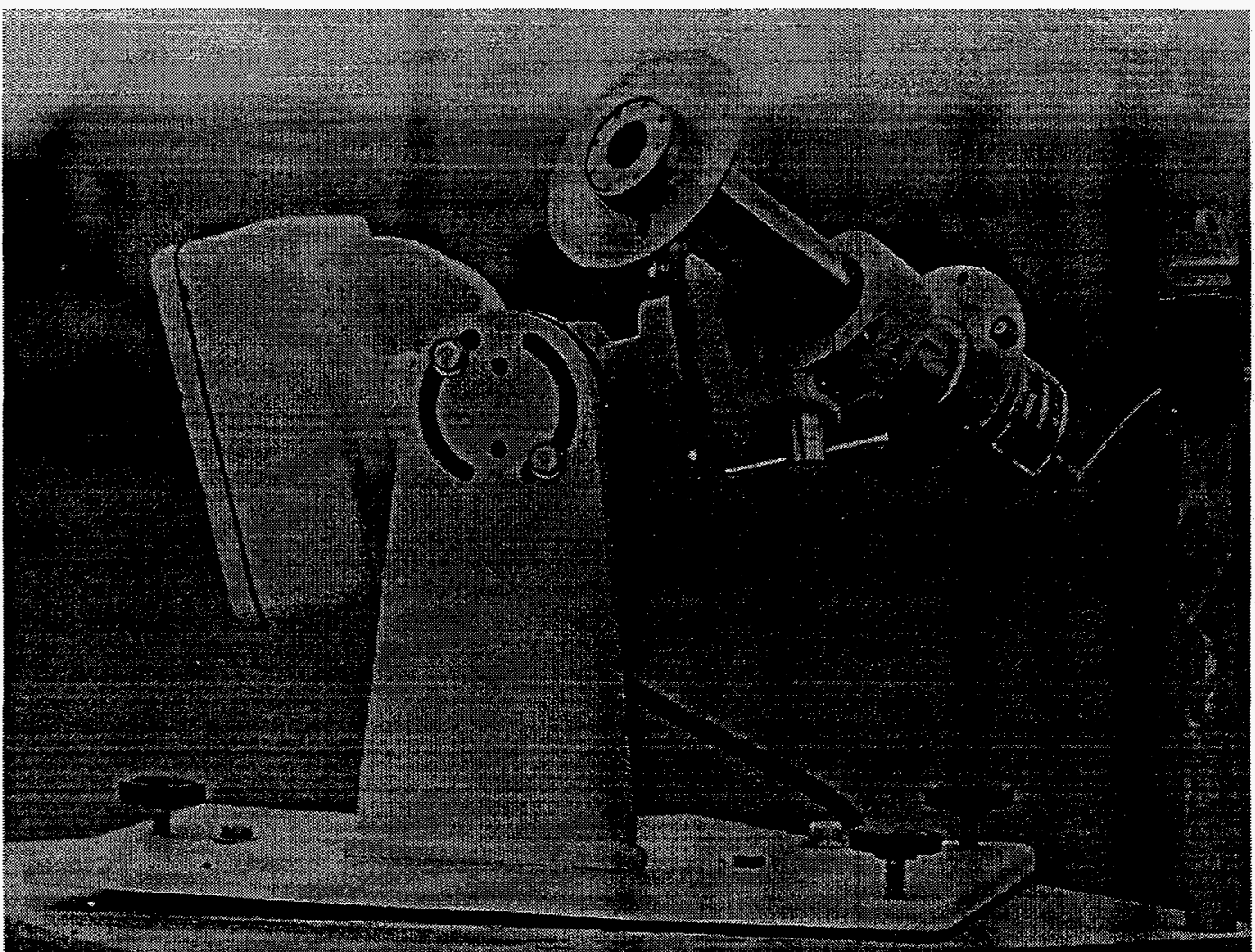

Figure 11. The Eppley Pyrheliometer and Solar Tracker.

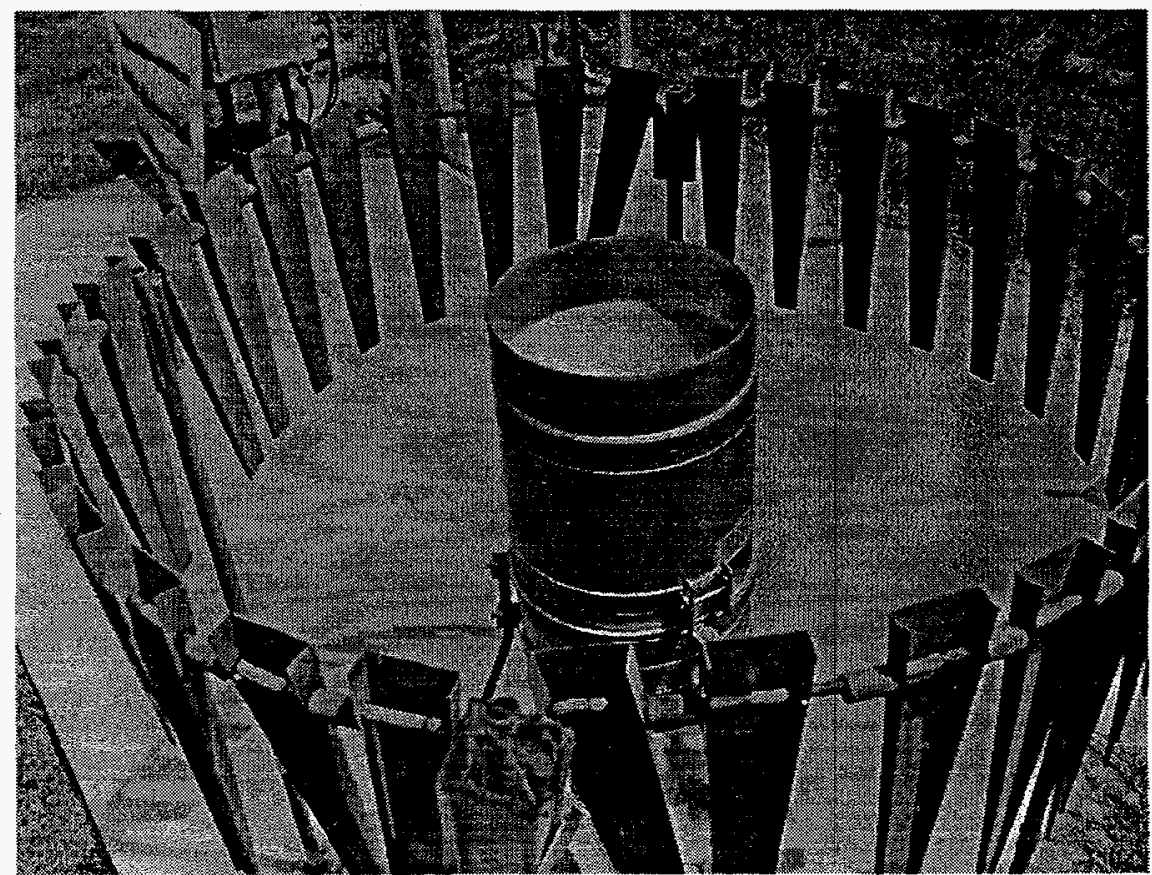

Figure 12. The Belford Tipping Bucket Rain Gauge, Model 5-405HA. 


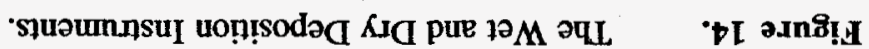

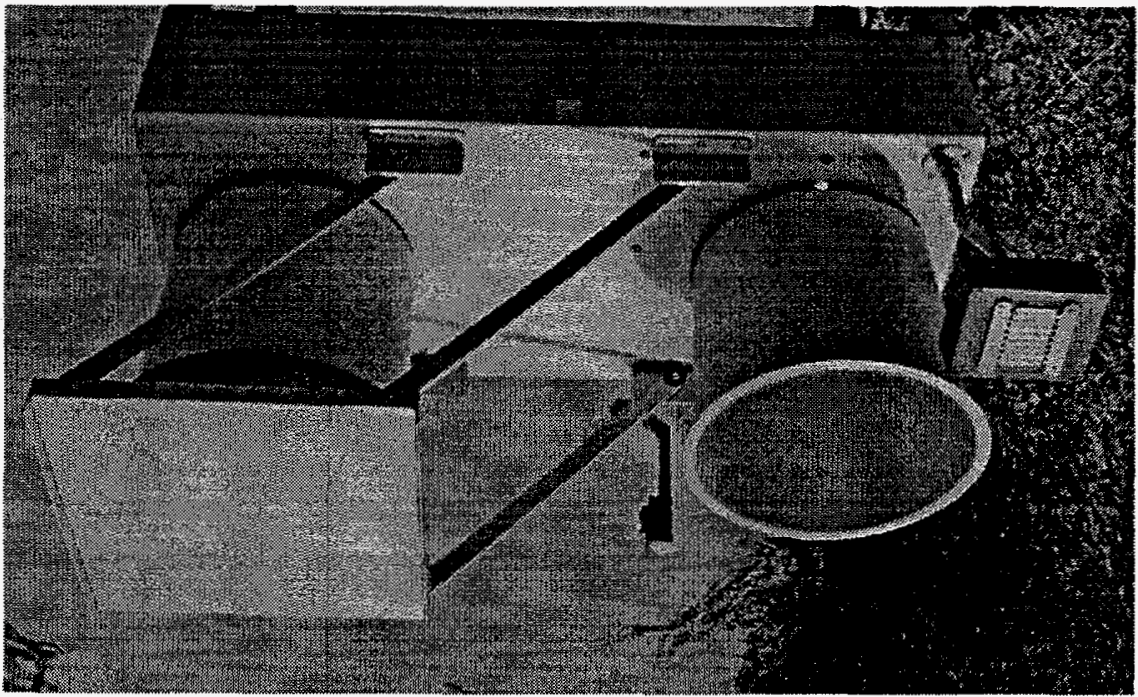

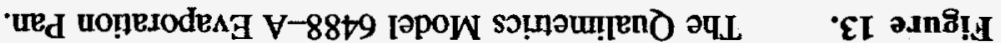

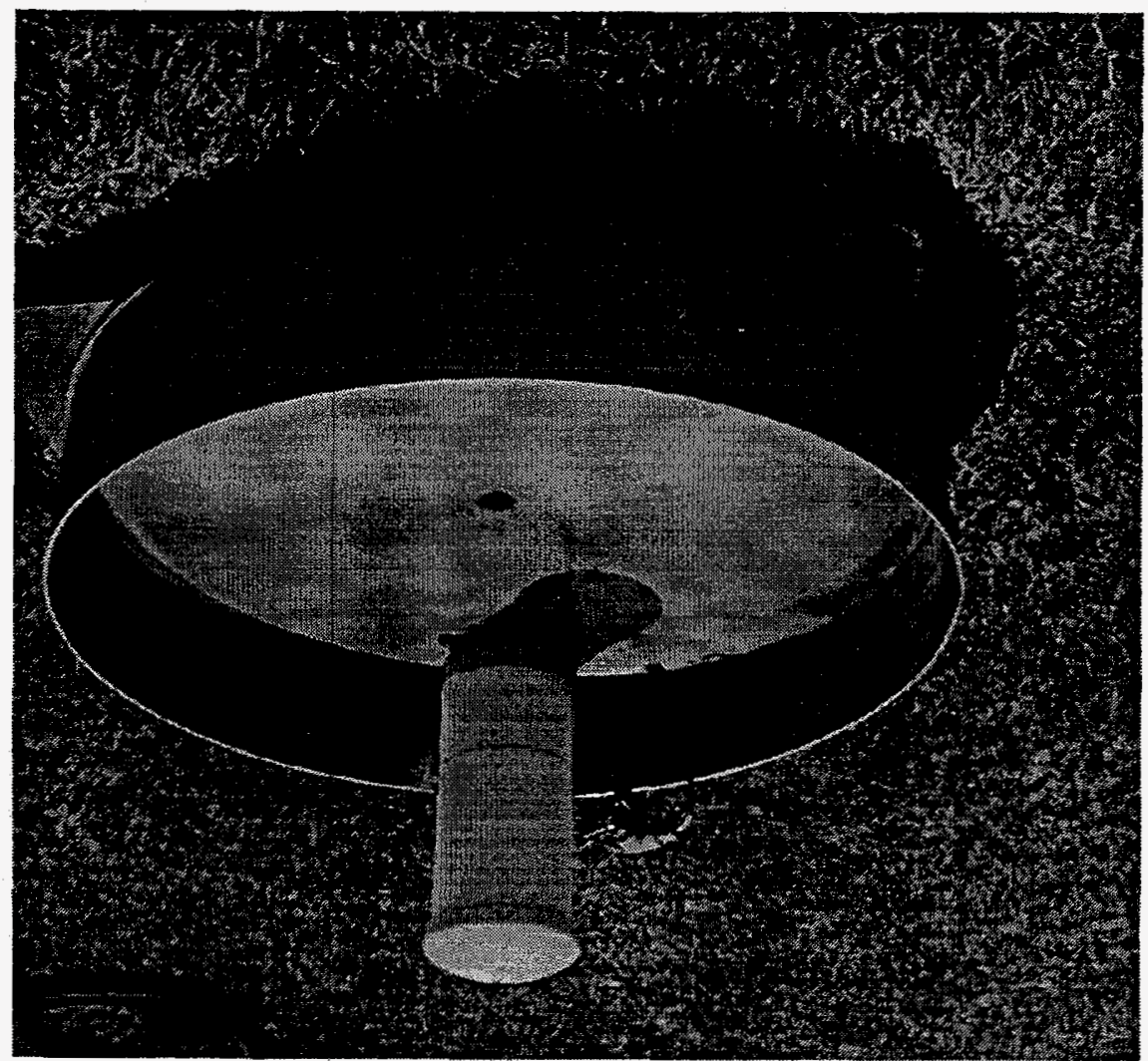




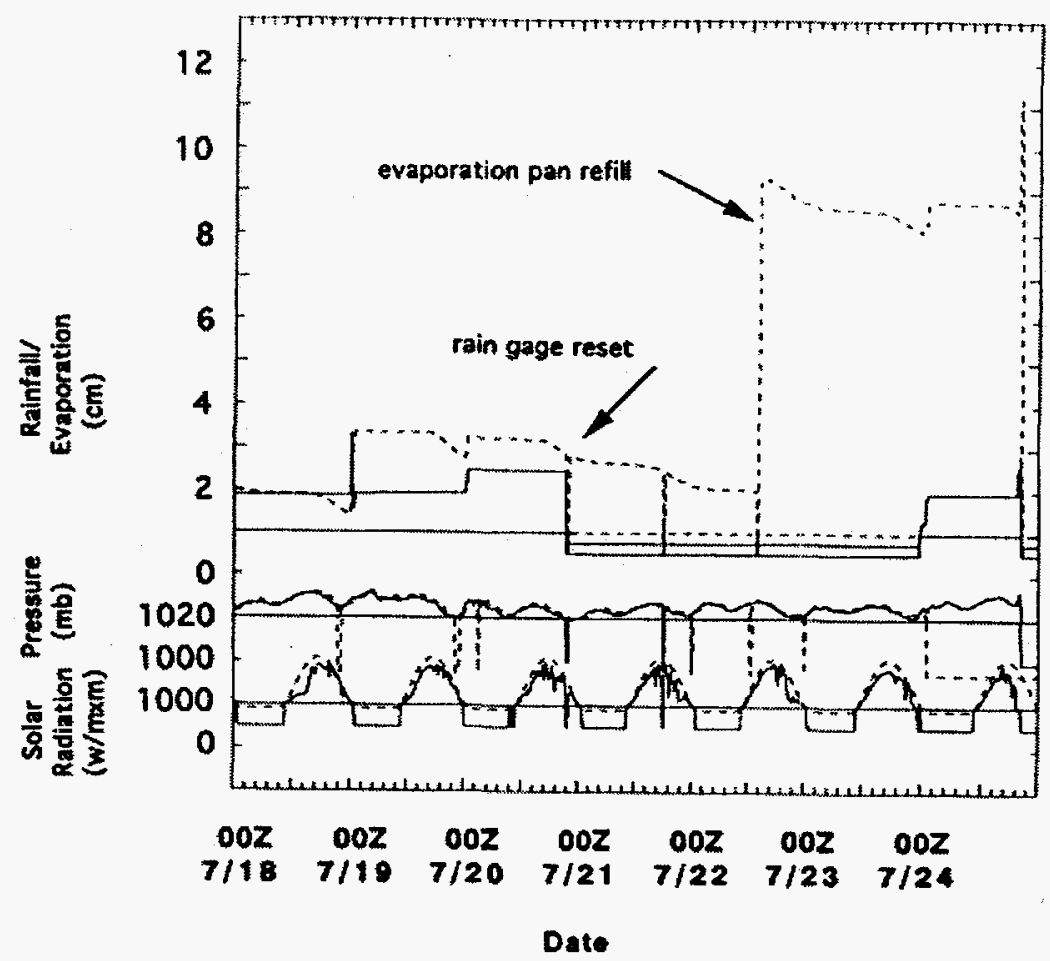

Figure 15. Weekly plots of the solar radiation, barometric pressure, rain gauge, and evaporation pan at the Climatology site. The dashed line on the solar radiation plot shows the theoretical clear-sky expected value for each day. The dashed pressure plot is for Bush Field in Augusta, GA (corrected for elevation difference). The dashed line in the top half of the figure is the depth of water in the evaporation pan. Note the manual refill of the pan on 22 July. The rain gauge is indicated with a solid line. Note the reset which occurred on 20 July. 


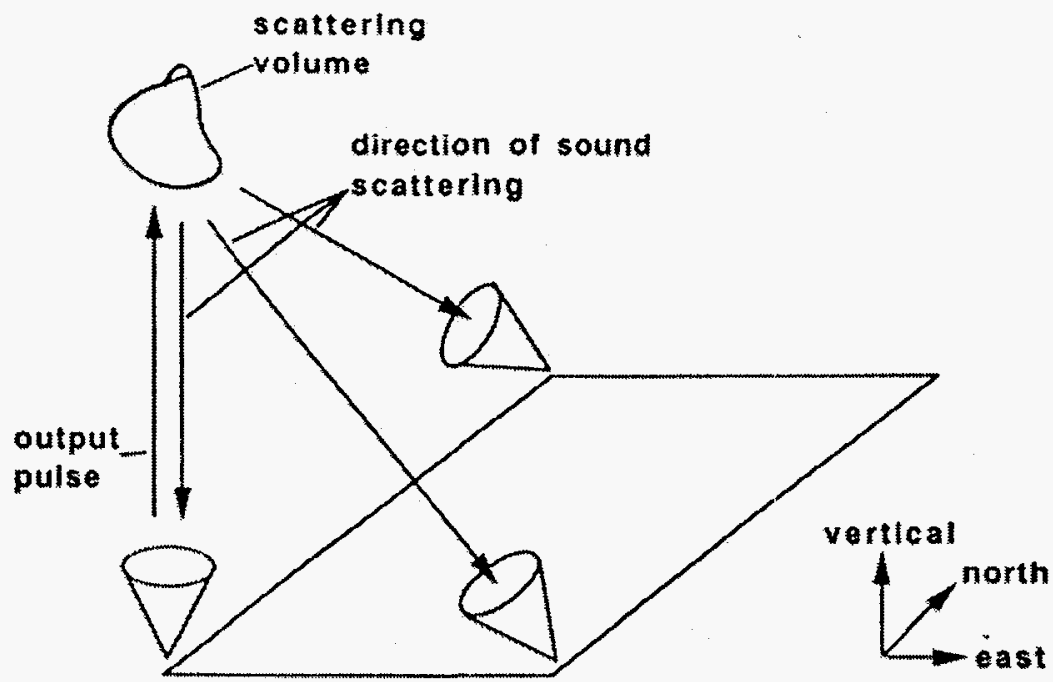

Figure 16. Geometry for the Bistatic SODAR at the Climatology site. 


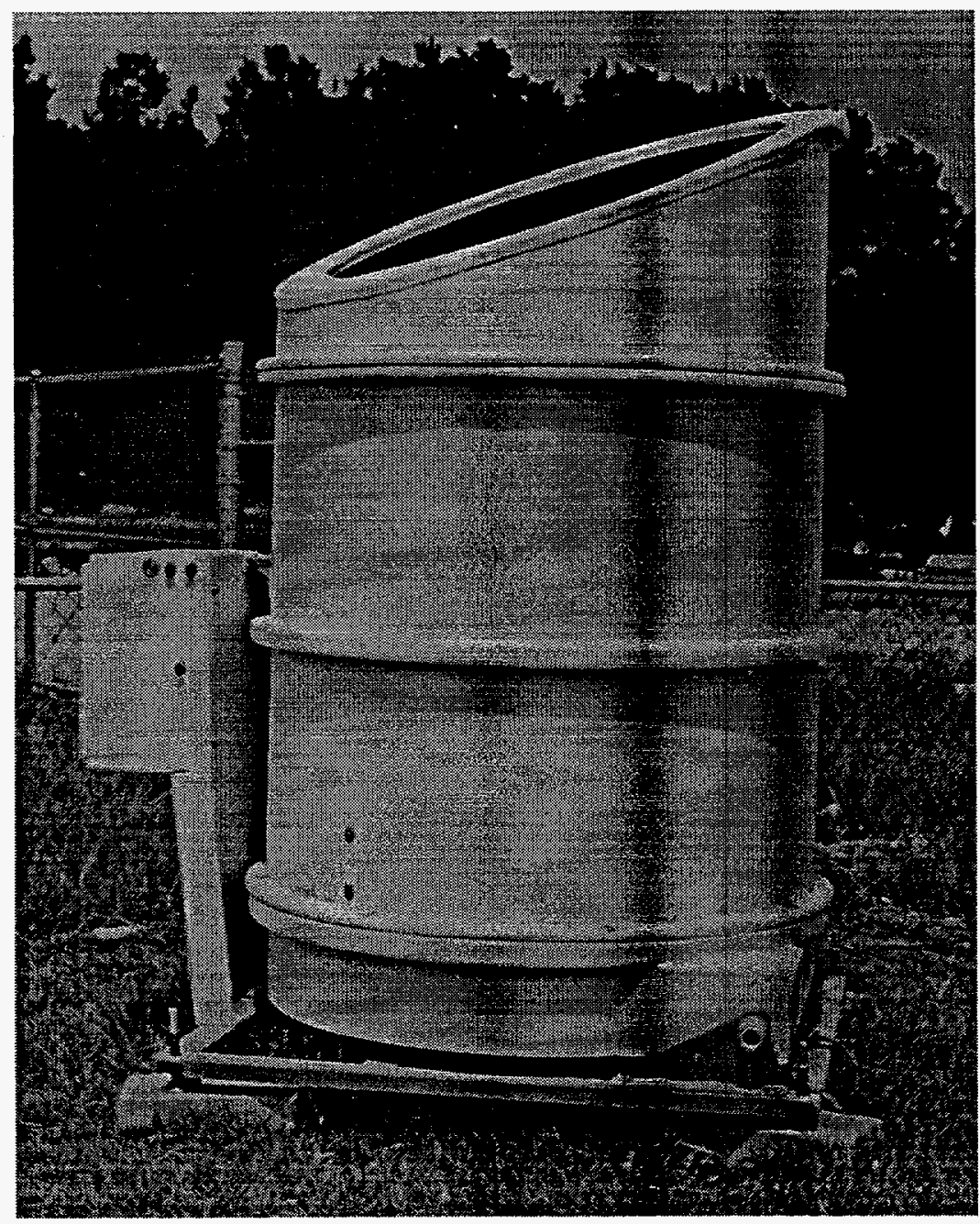

Figure 17. The vertical Bistatic Antenna at the Climatology site. 


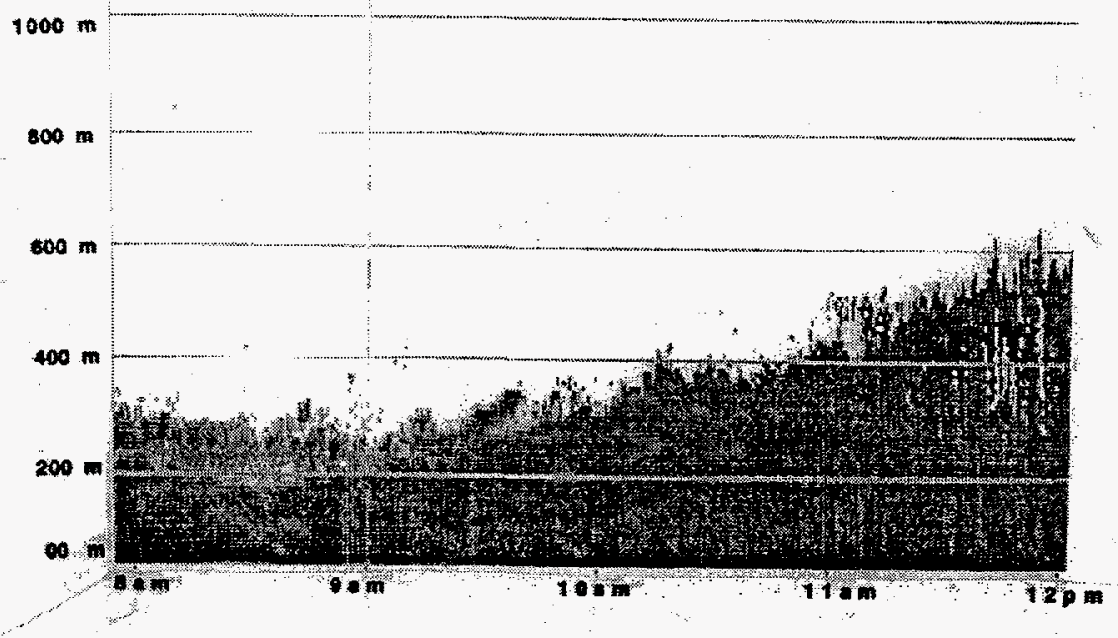

Figure 19. Return echo from the Bistatic SODAR. The darkness of the shading is porportional to the magnitude of the turbulence.

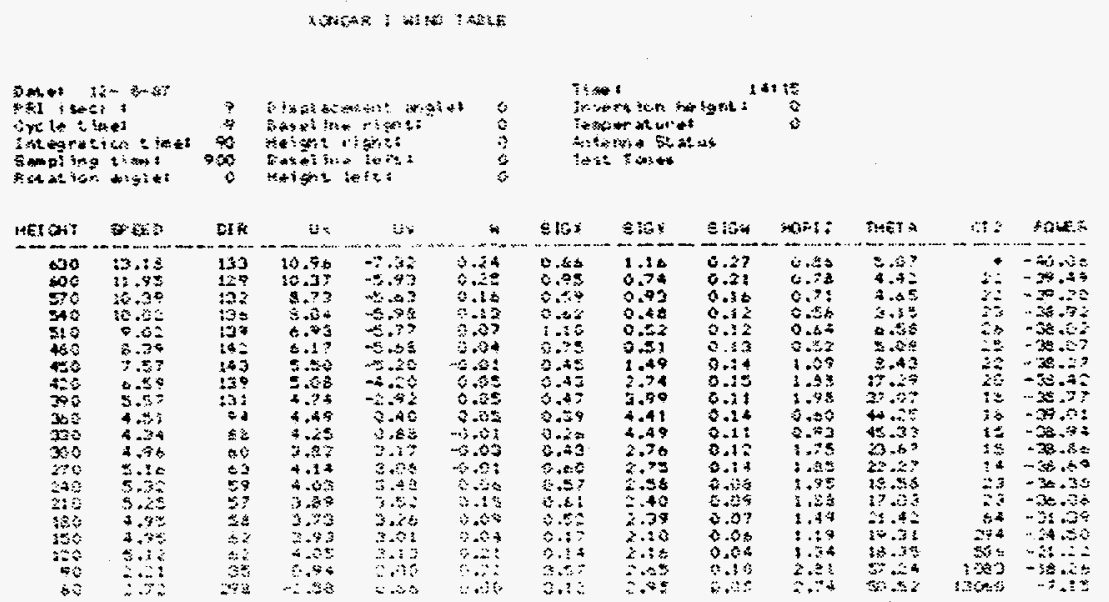

Figure 20. Wind table from the Bistatic SODAR. The heights are in meters. 


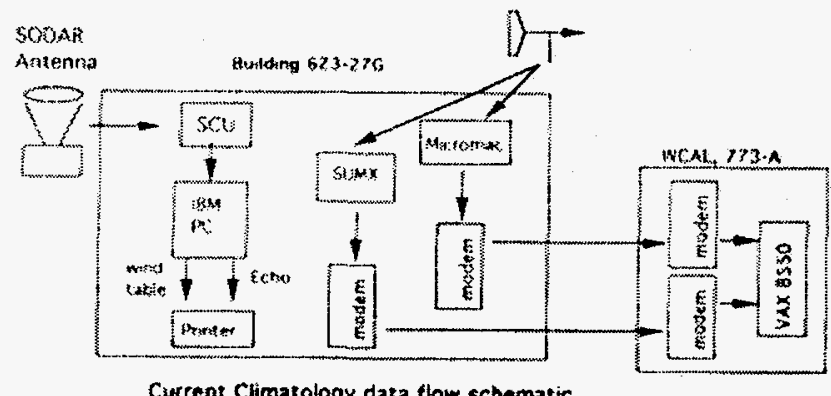

Current Climatology dato flow schematic

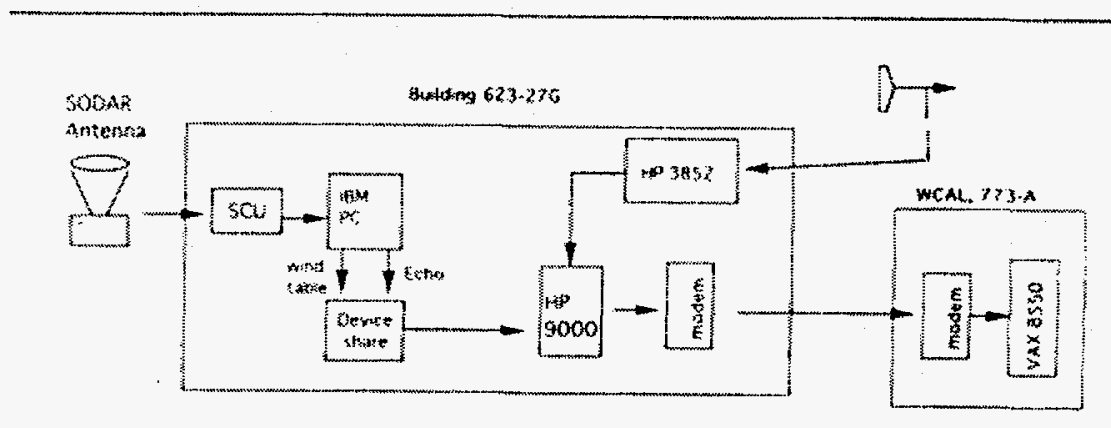

Planned Climatology data flow schematic

Figure 21. Current and proposed data flow schematic for the Climatology site. 
PYRANOMETER ACCURACY

Procedure ETSP T105.1

Area: Climatology Date:

Operator:

Equipment to be tested: Eppley Black and White Pyranomeler Model 8448, S/N:

Processor card: Teledyne Amplifier Module 21.33. S/N Repl. S/N:

Field instrument Eppley $S / N$ :

Standard instrument Eppley $\mathrm{S} / \mathrm{N}$ :

Fluke Voltmeter Model \#

H_LIN

Calib. const. $(10-6 \mathrm{v} / \mathrm{Wm}-2)$ :

\% Cloudiness

Calib. const. $(10-6 \times / \mathrm{Wm}-2)$ :

Calibration Date:

Calibration Begin Time:

\begin{tabular}{|c|c|c|c|c|c|c|c|c|}
\hline & 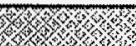 & & & $798 \%$ & & & & \\
\hline Obs & $\begin{array}{l}\text { Fluke vofts } \\
\text { (Standerd) }\end{array}$ & $\begin{array}{l}\text { Fluke votts } \\
\text { (Fiold unit) }\end{array}$ & $\begin{array}{l}\text { MAC vols } \\
\text { (Fiold unil) }\end{array}$ & $\begin{array}{l}\text { Radi, W/m2 } \\
\text { (Standard) }\end{array}$ & $\begin{array}{l}\text { Fod, Wim? } \\
\text { (Fiald unit) }\end{array}$ & $\begin{array}{l}\text { Diff, W/m2 } \\
\text { (Std-Fiak) }\end{array}$ & $\begin{array}{l}\text { Exp. MAC volts } \\
\text { Fiekdx } 333.3\end{array}$ & $\begin{array}{l}\text { Diff., volts }= \\
\text { (MAC-Exp) }\end{array}$ \\
\hline 1 & & & & & & & & \\
\hline 2 & & & & & & & & \\
\hline 3 & & & & & & & & \\
\hline
\end{tabular}

Tolerance $=15 \mathrm{~W} / \mathrm{m} 2$

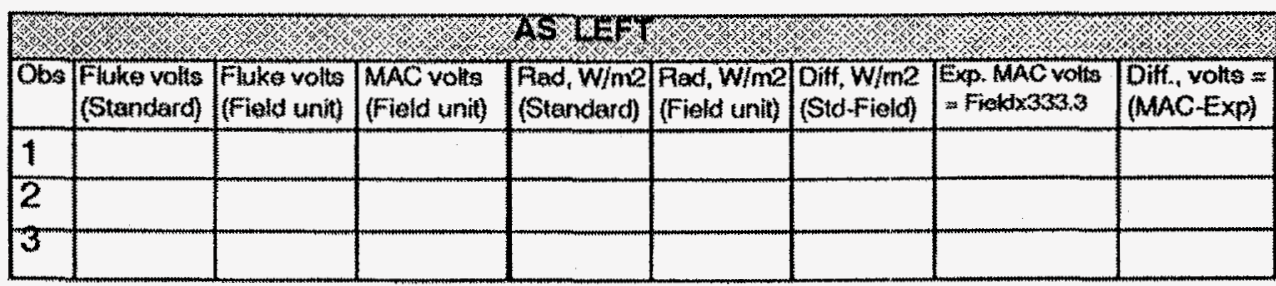

Tolerance $=15 \mathrm{~W} / \mathrm{m} 2$

\begin{tabular}{|c|c|c|c|c|c|c|c|c|c|c|}
\hline K⿰氵 & s & & & $\mathrm{Pan}$ & d Callora & 10ros swite & & & & \\
\hline Condition & $\begin{array}{l}\text { Pand } \\
\text { sat }\end{array}$ & Voltage & $\begin{array}{l}\text { Fike } \\
\text { Pass }\end{array}$ & $\begin{array}{l}\text { Fluke } \\
\text { Eail }\end{array}$ & $\begin{array}{l}\text { Previkus } \\
\text { As Lefluace }\end{array}$ & $\begin{array}{l}\text { Difference } \\
\text { ferev-MACl }\end{array}$ & $\begin{array}{c}\text { Expected } \\
\text { volts }\end{array}$ & $\begin{array}{c}\text { Error } \\
\text { (ExA-MAC) }\end{array}$ & OK & Adqust \\
\hline As found & $\begin{array}{l}10 \\
\text { Fluke }\end{array}$ & $\begin{array}{l}\text { Fluke= } \\
\text { MAC= } \\
\text { MAC= }\end{array}$ & & & & & 0.0 & & & \\
\hline Astound & FII & MACE= & & 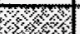 & & & 5.0 & & & \\
\hline Asleft & LO & MAC $=$ & & & & & 0.0 & & & \\
\hline AE & का & MAC $=$ & & & & & 50 & & & \\
\hline
\end{tabular}

New instrument? $\mathrm{Y} / \mathrm{N}$ :

Calibration end time:

Time the new coefficient was entered with wicoef_cl:

Comments:

Figure 22. Pyranometer Calibration Form - FORM OP-PY. 
-Iə⿱一⿻上丨)

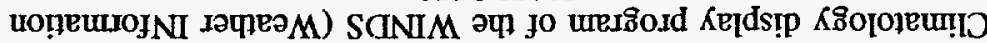

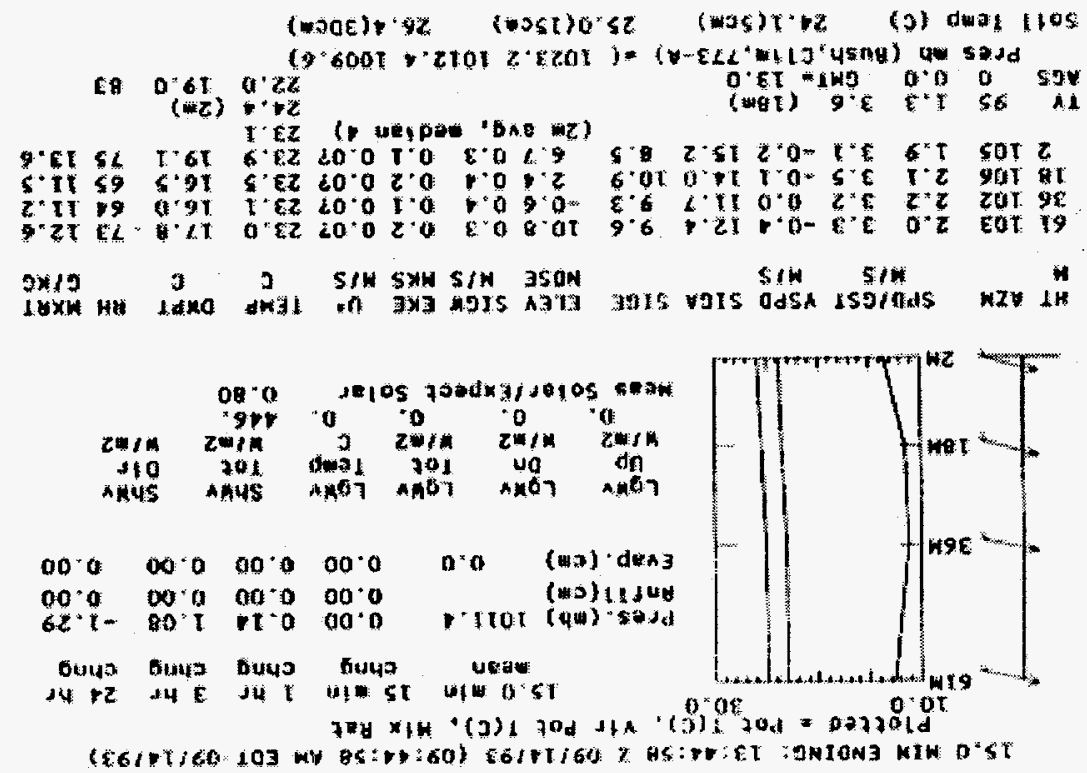


3:00 am

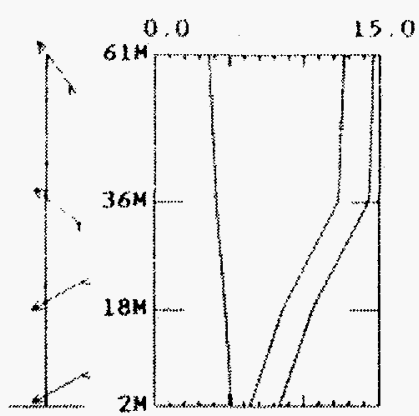

HI AZM SPDIGST YSPO SIGA SIGE

M

$\begin{array}{lllllll}61 & 1.44 & 2.3 & 2.7 & 0.7 & 2.4 & 0.5\end{array}$

$\begin{array}{lllllll}36 & 127 & 2.0 & 2.3 & 0.0 & 5.9 & 0.7\end{array}$

$\begin{array}{lllllll}18 & 62 & 0.6 & 0.9 & 0.0 & 28.5 & 1.6\end{array}$

$\begin{array}{llllllll}2 & 62 & 0.5 & 0.9 & 0.0 & 24.6 & 1.3\end{array}$

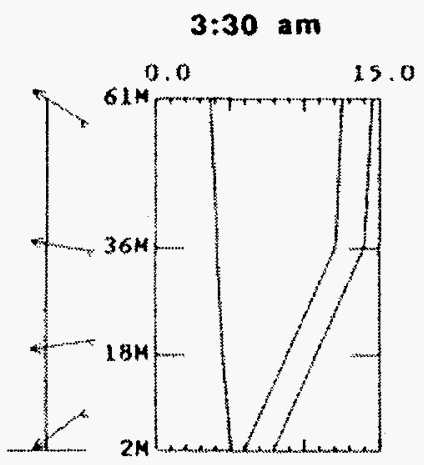

\begin{tabular}{lrrrrrr} 
HI & AZM & \multicolumn{3}{c}{ SPOIGST VSPD } \\
MIS & $\begin{array}{c}\text { HIS } \\
\text { HIGA SIGE }\end{array}$ \\
61 & 122 & 2.2 & 2.6 & 0.7 & 2.7 & 0.7 \\
36 & 92 & 2.4 & 2.8 & 0.0 & 5.8 & 1.0 \\
18 & 81 & 1.1 & 1.4 & 0.0 & 7.8 & 3.1 \\
2 & 53 & 0.6 & 1.3 & 0.0 & 6.7 & 1.6
\end{tabular}
3:15 am

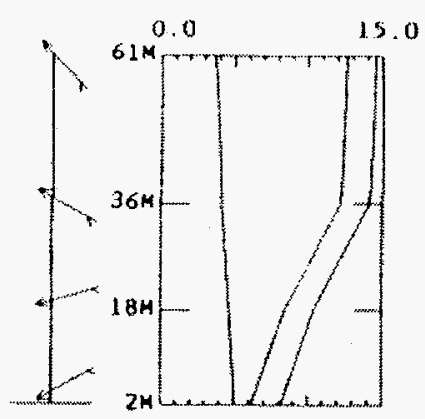

HT AZM SPOIGST VSPO SIGA SIGE

$\begin{array}{lllllll}61 & 139 & 2.3 & 2.6 & 0.7 & 5.8 & 0.5\end{array}$

$\begin{array}{lllllll}36 & 119 & 2.2 & 2.5 & 0.0 & 5.3 & 1.2\end{array}$

$\begin{array}{lllllll}18 & 32 & 0.9 & 1.4 & 0.0 & 22.7 & 2.4\end{array}$

$\begin{array}{lllllll}2 & 59 & 0.6 & 1.1 & 0.0 & 23.6 & 1.2\end{array}$

$3: 45$ am

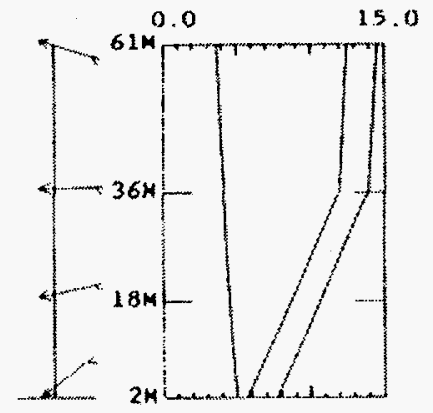

Mr AZM SPDIGST VSPO SIGA SIGE

M MIS MIS

$\begin{array}{lllllll}61 & 108 & 2.6 & 3.2 & 0.8 & 3.7 & 0.5\end{array}$

36 B $3.1 \quad 3.70 .11 .71 .2$

$\begin{array}{lllllll}18 & 78 & 1.6 & 2.6 & 0.0 & 6.7 & 3.8\end{array}$

Figure 24. Plots of wind data for 15-minute periods between 3:00 am and 4:00 am on 8 April 1993. 


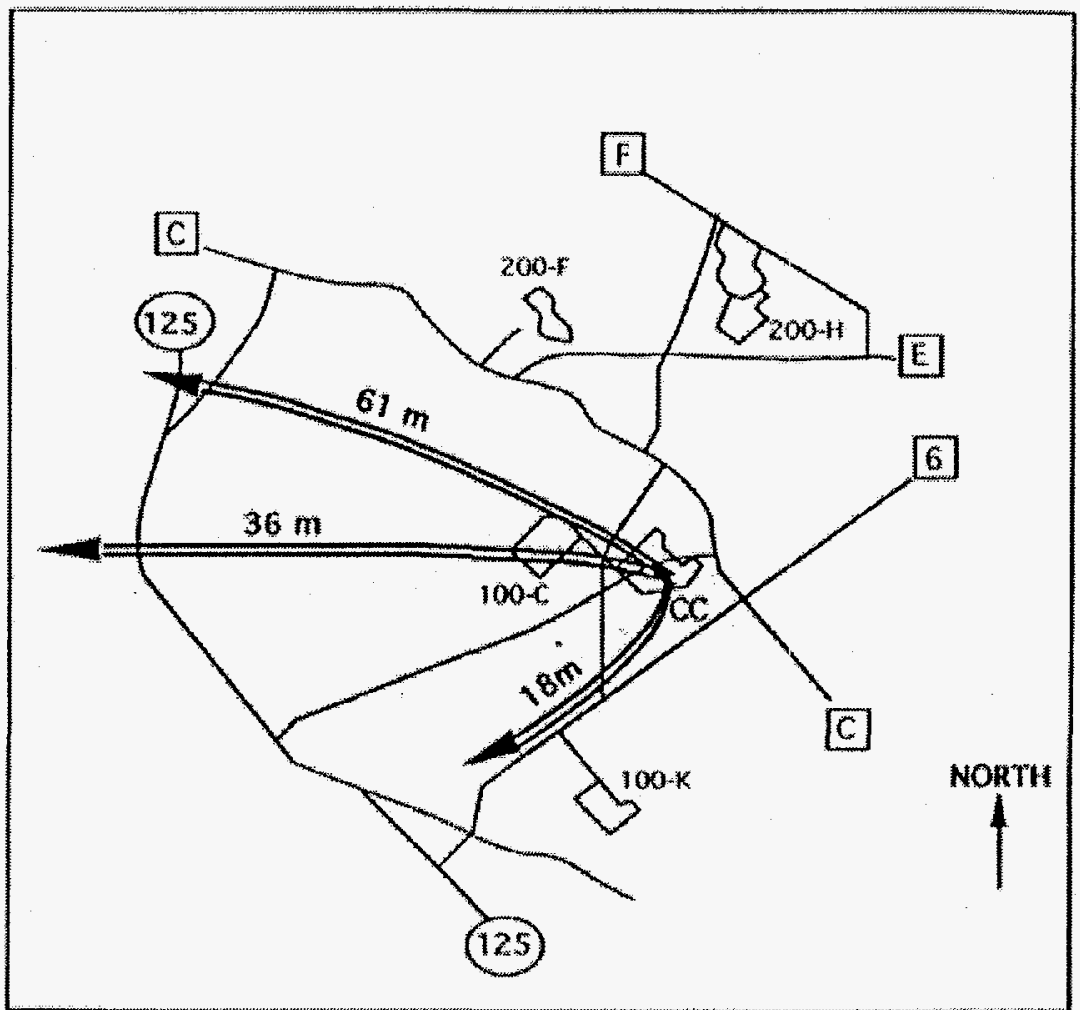

Figure 25. One hour air trajectories of air parcels at 18,36, and 61-meters between 3:00 am and 4:00 am on 8 April 1993.

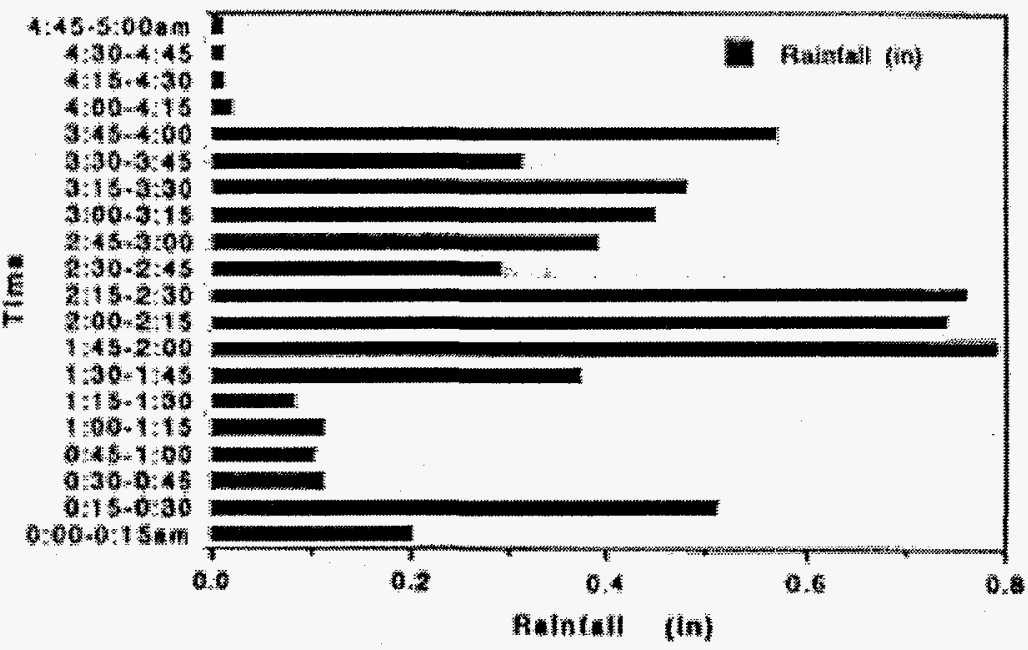

Figure 26. Rainfall in inches on 22 August 1990 at the Climatology site between 12:00 am and 5:00 pm. 


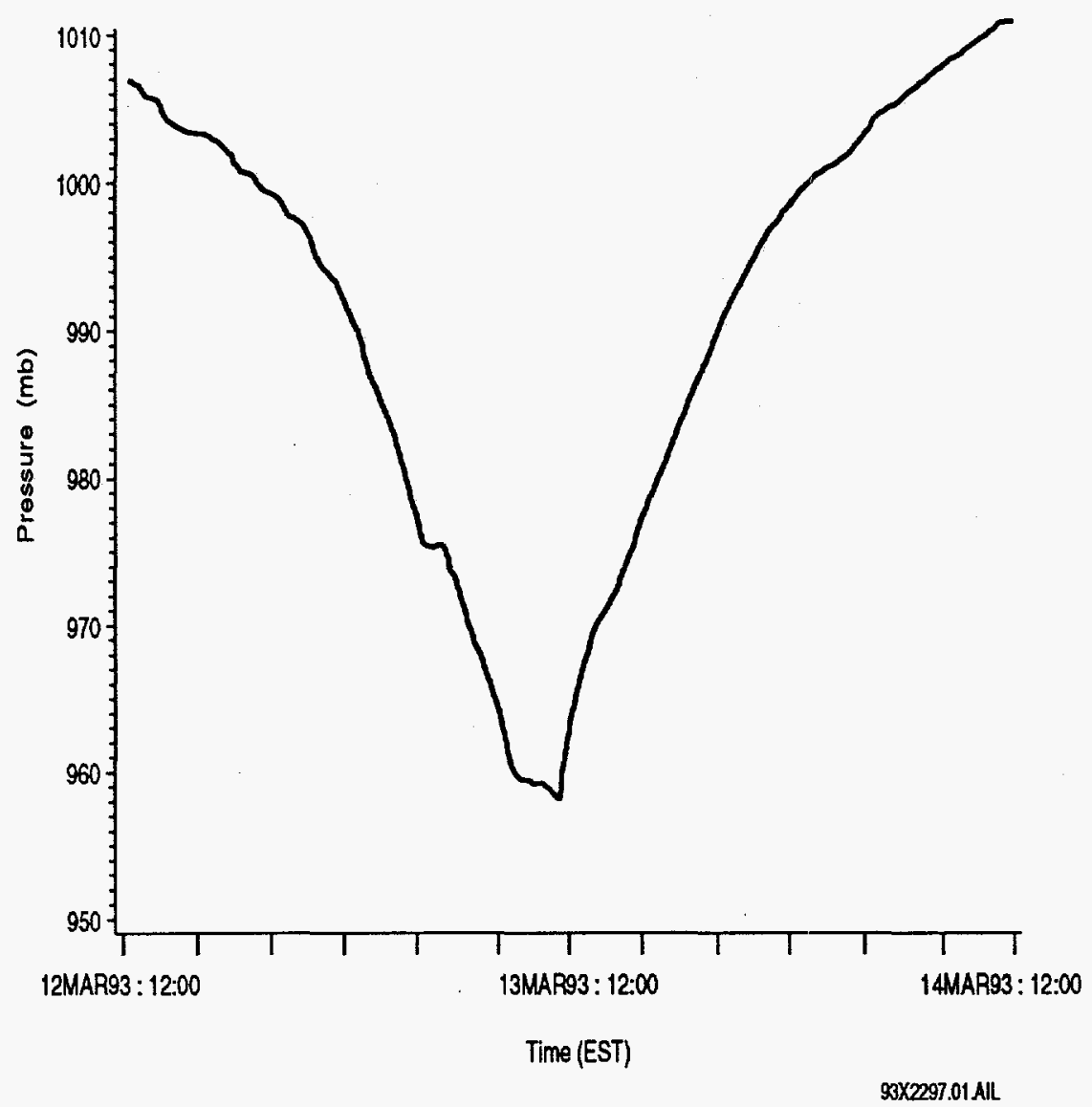

Figure 27. Pressure trace at the Climatology Site during the "storm of the century" on March 12-14, 1993. 